\title{
Metformin: Expanding the Scope of Application-Starting Earlier than Yesterday, Canceling Later
}

\author{
Yulia A. Kononova, Nikolai P. Likhonosov and Alina Yu. Babenko *
}

National Almazov Medical Research Centre, Institute of Molecular Biology and Genetics, 197341 Saint-Petersburg, Russia; ncmu@almazovcentre.ru (Y.A.K.); likhonosov.pn@gmail.com (N.P.L.)

* Correspondence: alina_babenko@mail.ru

\begin{abstract}
Today the area of application of metformin is expanding, and a wealth of data point to its benefits in people without carbohydrate metabolism disorders. Already in the population of people leading an unhealthy lifestyle, before the formation of obesity and prediabetes metformin smooths out the adverse effects of a high-fat diet. Being prescribed at this stage, metformin will probably be able to, if not prevent, then significantly reduce the progression of all subsequent metabolic changes. To a large extent, this review will discuss the proofs of the evidence for this. Another recent important change is a removal of a number of restrictions on its use in patients with heart failure, acute coronary syndrome and chronic kidney disease. We will discuss the reasons for these changes and present a new perspective on the role of increasing lactate in metformin therapy.
\end{abstract}

Keywords: diabetes mellitus; obesity; metformin; molecular mechanisms; atherosclerosis; cardiovascular diseases; heart failure; chronic kidney disease; lactate

\section{Introduction}

More and more data demonstrate that the start of a metabolic disorders cascade leading

Citation: Kononova, Y.A.; Likhonosov, N.P.; Babenko, A.Y. Metformin: Expanding the Scope of Application-Starting Earlier than Yesterday, Canceling Later. Int. J. Mol. Sci. 2022, 23, 2363. https://doi.org/ $10.3390 /$ ijms 23042363

Academic Editor: Masashi Tanaka

Received: 31 December 2021

Accepted: 18 February 2022

Published: 21 February 2022

Publisher's Note: MDPI stays neutral with regard to jurisdictional claims in published maps and institutional affiliations.

Copyright: (c) 2022 by the authors. Licensee MDPI, Basel, Switzerland. This article is an open access article distributed under the terms and conditions of the Creative Commons Attribution (CC BY) license (https:// creativecommons.org/licenses/by/ $4.0 /)$. to both diabetes mellitus (DM) and associated cardiovascular (CV) problems occurs with a hypercaloric diet high in fat and carbohydrates with a high glycemic index. As current studies have shown, such nutritional characteristics are associated with an increased risk of cardiovascular diseases (CVDs) even before the development of obesity and diabetes [1-3]. Normally, excess nutrients are deposited in subcutaneous adipose tissue (SAT); however, a metabolic health disorder is associated with a shift in the deposition of fats in the visceral depot and with deposition because of hyperplasia of adipocytes to their hypertrophy, an increase in volume [4,5].

Mechanisms of reprogramming the location and nature of the deposition of excess nutrients are being actively studied. The way of an expansion and remodeling of white adipose tissue (WAT) directly affects the risk of insulin resistance (IR) and metabolic syndrome development in obesity. Predominant WAT accumulation in the visceral depot is associated with an increased risk of IR, whereas subcutaneous WAT accumulation is protective for metabolic health. The processes of nutrient deposition can also differ-occurring either by hyperplasia of adipocytes or by hypertrophy [6]. Pathological remodeling of WAT is characterized by adipocyte hypertrophy accompanied by chronic inflammation and fibrosis and is associated with IR. A "healthy" variant of nutrient accumulation suggests WAT hyperplasia, where adipocytes have a significantly smaller volume, and the severity of inflammation and fibrosis is minimal [6]. This "metabolically healthy" variant of obesity is characterized by normal insulin sensitivity and the absence of metabolic disorders, including type $2 \mathrm{DM}$.

The role of nutrient exposure through the microbiome composition and functioning in the transition from metabolically healthy to metabolically unhealthy obesity.

In recent years, several mechanisms linking the gut microbiota with the development of obesity and associated metabolic disorders (IR, type 2 diabetes) have been identified. 
There is accumulating evidence of a causal relationship between the imbalance in normal populations of microorganisms in the human gastrointestinal tract (GIT) and the development of obesity, IR, type 2 DM, and CVD [7,8]. Bacteria of the phylotypes Bacteroidetes and Firmicutes predominate in the microbiota of the digestive tract in healthy adults $[9,10]$. Glyco- and lipotoxic effects of nutrients rich in animal fats and rapid carbohydrates lead to an imbalance in various subtypes of bacteria that form the human GIT microbiota [11]. With the progress of obesity, a relative decrease in Bacteroidetes in relation to Firmicutes occurs, the contribution of Actinobacteria changes, and the numbers of butyrate and lactateproducing bacteria decrease [12]. Type $2 \mathrm{DM}$ is characterized by a greater imbalance in the composition of the microbiome (Table 1) [13-18].

Table 1. Key effects of metformin at different stages of disorders of carbohydrate metabolism.

\begin{tabular}{|c|c|c|c|}
\hline Stage & Key Pathogenetic Disturbances & Key Effects of Metformin & References \\
\hline \multirow[t]{2}{*}{$\begin{array}{l}\text { No obesity, no carbohydrate } \\
\text { metabolism disorders, leading } \\
\text { an unhealthy lifestyle } \\
\text { (consuming hypercaloric, } \\
\text { fat-rich and high glycemic } \\
\text { index food) (results of clinical } \\
\text { and experimental studies) }\end{array}$} & $\begin{array}{l}\text { high-fat and carbohydrate-rich food } \\
\text { with a high glycemic index } \rightarrow \text { change } \\
\text { of microbiome composition: } \\
\text { - } \quad \downarrow \text { abundance of Bacteroidetes } \rightarrow \\
\quad \downarrow \text { production of SCFAs (acetate } \\
\text { and propionate) which improve } \\
\text { insulin sensitivity; } \\
\quad \downarrow \text { abundance of bacteria of the } \\
\text { genus Lactobacillus } \rightarrow \downarrow \\
\text { production of their metabolites } \\
\text { (lactate), which are key } \\
\text { modulators of glucose } \\
\text { metabolism in the } \\
\text { gastrointestinal tract and } \\
\text { expression of SGLT-1; } \\
\downarrow \text { abundance of } \\
\text { butyrate-producing bacteria } \\
\text { (Butyricimonas spp. and } \\
\text { Allobaculum) } \rightarrow \downarrow \text { production } \\
\text { of their metabolite (butyrate), } \\
\text { which increases insulin } \\
\text { sensitivity and the secretion of } \\
\text { intestinal hormones, in } \\
\text { particular incretins }\end{array}$ & $\begin{array}{l}\text { despite maintaining a high-fat diet, } \\
\text { restoration of the abundance of: } \\
\text { - } \quad \text { Bacteroides, the genus of the } \\
\text { phylum Bacteroidetes; } \\
\text { - } \quad \text { butyrate-producing bacteria } \\
\text { in the intestine (Butyricimonas } \\
\text { spp. and Allobaculum); } \\
\text { - Parabacteroides, a succinate } \\
\text { producer } \\
\uparrow \text { concentration of SCFAs (butyrate } \\
\text { and propionate) in fecal samples } \\
\text { from people receiving metformin }\end{array}$ & [19-30] \\
\hline & $\begin{array}{l}\downarrow \text { secretion of incretins (mainly } \\
\text { GLP-1) and sensitivity to them } \\
\text { (GLP-1 and GIP) }\end{array}$ & $\begin{array}{l}\text { in the experiment: } \uparrow \text { production of } \\
\text { GLP- } 1 \text {, but not GIP; activation of } \\
\text { the expression of tissue receptors of } \\
\text { GLP-1 and GIP, } \uparrow \text { tissue sensitivity } \\
\text { to both incretins }\end{array}$ & [31] \\
\hline
\end{tabular}


Table 1. Cont.

\begin{tabular}{|c|c|c|c|}
\hline Stage & Key Pathogenetic Disturbances & Key Effects of Metformin & References \\
\hline & $\begin{array}{l}\text { high-fat diet } \rightarrow \uparrow \text { intestinal } \\
\text { permeability for LPS, } \downarrow \text { abundance of } \\
\text { A. muciniphila, } \downarrow \text { mucin production, } \\
\downarrow \text { its anti-inflammatory effects with } \uparrow \\
\text { levels of IL- } 6 \text { and IL- } 1 \beta\end{array}$ & $\begin{array}{l}\text { modulation of the expression of the } \\
\text { MUC2 and MUC5 genes } \rightarrow \uparrow \\
\text { mucin level, } \uparrow \text { abundance of A. } \\
\text { muciniphila, which is involved in } \\
\text { mucin production } \rightarrow \downarrow \text { intestinal } \\
\text { permeability for LPS } \\
\uparrow \text { MUC2 expression } \rightarrow \uparrow \\
\text { production of mucin proteins } \\
\text { zonulin- } 1 \text { and occludin } \rightarrow \downarrow \\
\text { intestinal permeability } \\
\uparrow \text { abundance of A. muciniphila } \rightarrow \downarrow \\
\text { level of IL- } 6 \text { and IL- } 1 \beta\end{array}$ & {$[19,20,22,32-35]$} \\
\hline & $\begin{array}{l}\downarrow \text { production of secondary bile acids } \\
\text { (deoxycholic acid and lithocholic } \\
\text { acid), that are formed with the } \\
\text { participation of enzymes and } \\
\text { intestinal microbiota and play a } \\
\text { significant role in glucose and lipids } \\
\text { metabolism in the } \\
\text { gastrointestinal tract }\end{array}$ & $\begin{array}{l}\text { slowing down bile acids } \\
\text { metabolism in the intestine } \rightarrow \\
\text { prolongation of bile acids action } \rightarrow \\
\text { improving of the metabolism of } \\
\text { lipids and glucose }\end{array}$ & [36-39] \\
\hline & $\begin{array}{l}\text { modulation of intestine-CNS axis: } \\
\text { high-fat diet } \rightarrow \text { impairment of the } \\
\text { production of microbiota metabolites } \\
\text { (SCFAs), which have a multilevel } \\
\text { effect on the regulation of } \\
\text { eating behavior } \\
\text { SCFAs } \rightarrow \uparrow \text { secretion of intestinal } \\
\text { hormones (serotonin, ghrelin, CCK, } \\
\text { PYY and GLP-1), which regulate the } \\
\text { secretion of insulin, gastric juice and } \\
\text { bile acids, and VN activity }\end{array}$ & $\begin{array}{l}\text { restoration of the abundance of } \\
\text { bacteria of the genus Lactobacillus } \\
\text { and } \uparrow \text { abundance of Bacteroides, the } \\
\text { genus in the phylum Bacteroidetes, } \\
\text { butyrate-producing bacteria } \\
\text { (Butyricimonas spp. and } \\
\text { Allobaculum), Parabacteroides, } \\
\text { producing succinate under the } \\
\text { influence of metformin, despite } \\
\text { maintaining a high-fat diet }\end{array}$ & \multirow[t]{3}{*}{ [36-39] } \\
\hline & $\begin{array}{l}\text { A number of SCFAs (acetate, } \\
\text { butyrate) } \rightarrow \text { penetration through BBB } \\
\rightarrow \text { direct participation in the } \\
\text { regulation of satiety and inhibition of } \\
\text { inflammation of CNS }\end{array}$ & $\begin{array}{l}\uparrow \text { production of SCFAs, evidenced } \\
\text { by an } \uparrow \text { concentration of SCFA } \\
\text { (butyrate and propionate) in fecal } \\
\text { samples from people receiving } \\
\text { metformin }\end{array}$ & \\
\hline & $\begin{array}{l}\text { SCFA } \rightarrow \text { inhibition of fat } \\
\text { accumulation in the adipose tissue, } \\
\text { enhancing its utilization, and } \\
\text { improvement of sensitivity to leptin } \\
\text { and ghrelin }\end{array}$ & $\begin{array}{l}\text { improvement in the functional state } \\
\text { of the intestine-CNS axis }\end{array}$ & \\
\hline Obesity & $\begin{array}{l}\downarrow \text { Bacteroidetes in relation to } \\
\text { Firmicutes } \\
\text { change in the contribution of } \\
\text { Actinobacteria, } \downarrow \text { in the number of } \\
\text { butyrate and lactate-producing } \\
\text { bacteria }\end{array}$ & $\begin{array}{l}\text { restoration of the abundance of } \\
\text { bacteria of the genus Lactobacillus } \\
\text { and } \uparrow \text { in the abundance of } \\
\text { Bacteroides, the genus in the } \\
\text { phylum Bacteroidetes, } \\
\text { butyrate-producing bacteria } \\
\text { (Butyricimonas spp. and } \\
\text { Allobaculum) }\end{array}$ & {$[34,35]$} \\
\hline
\end{tabular}


Table 1. Cont.

\begin{tabular}{|c|c|c|c|}
\hline Stage & Key Pathogenetic Disturbances & Key Effects of Metformin & References \\
\hline & $\begin{array}{l}\uparrow \text { plasma levels of LPS after high-fat } \\
\text { meals compared with people without } \\
\text { obesity } \\
\uparrow \text { penetration of LPS into the } \\
\text { bloodstream, their accumulation in } \\
\text { adipocytes with the development of } \\
\text { their hypertrophy, insulin resistance, } \\
\text { inflammation, internalization of } \\
\text { LPS-lipoproteins by adipose tissue } \\
\text { macrophages, with a change in their } \\
\text { phenotype from M2 to M1-the } \\
\text { development of hypertrophic, } \\
\text { metabolically unhealthy obesity }\end{array}$ & $\begin{array}{l}\text { protective effect in LPS-induced } \\
\text { damage to epithelial cells of the } \\
\text { respiratory tract } \\
\text { in the experiment: } \\
\text { anti-inflammatory effects, induction } \\
\text { of ATF-3 in parallel with protective } \\
\text { effects against lipoprotein-induced } \\
\text { inflammation } \\
\text { in the experiment: suppression of } \\
\text { LPS-induced response of } \\
\text { macrophages and resolution of } \\
\text { allergic dermatitis by modulating } \\
\text { autophagy } \\
\downarrow \text { production of pro-inflammatory } \\
\text { cytokines in LPS-stimulated cells }\end{array}$ & {$[40-43]$} \\
\hline
\end{tabular}

greater $\downarrow$ Bacteroidetes and $\uparrow$ pool of Firmicutes Proteobacteria, $\downarrow$ bacteria of the genus Roseburia, a butyrate producer

abundance of Lactobacillus spp. was higher, than in healthy people which

Type 2 diabetes mellitus is regarded as an attempt at immunomodulation

$\uparrow$ abundance of Gram-negative bacteria $\rightarrow$ stimulation of the immune system through TLR and development of insulin resistance suppression of TLR 4 signaling, including after myocardial infarction, weakening left ventricle dysfunction; in myocardial dysfunction caused by sepsis; in lung endotheliocytes islet redox stress (oxidative and nitrosative stress), free-radical polymerization of islet amyloid polypeptide monomer, $\beta$-cell stress of endoplasmic reticulum, UPR stress

Latent and transient stage of diabetes at transient stage: joining of the processes of amyloidosis and fibrosis of $\beta$-cells $\rightarrow$ development of carbohydrate metabolism disorders regulating the activity of GRP78 $\rightarrow$ reduction of redox stress and normalization of the formation of

SCFAs—short-chain fatty acids; GLP-1—glucagon-like peptide-1; GIP—glucose-dependent insulinotropic peptide SGLT-1—sodium glucose cotransporter-1; LPS-lipopolysaccharides; IL-6—interleukin-6; IL-1 $\beta$-interleukin $1 \beta$; VN—vagus nerve; CCK - cholecystokinin; PYY - peptide YY; CNS — central nervous system; UPR — unfolded protein response; GRP-78 — glucose regulatory protein 78; TTLR—Toll-like receptors; DM—diabetes mellitus; ATF-3—transcriptional activation factor $3 ; \rightarrow$-affect; $\uparrow$ —increased; $\downarrow$-decreased.

The gut microbiota interact with the host organism through recognition receptorsToll-like receptors (TLRs). Obese people demonstrated a significantly greater increase in plasma lipopolysaccharide (LPS) levels after a high-fat meal compared to non-obese people [42]. Translocation of LPSs across the intestinal mucosa is a characteristic of obesity, type $2 \mathrm{DM}$, and related disorders. Eating a high-fat diet dose-dependently elevates the production of LPSs by Gram-negative bacteria in the intestine and facilitates their entry from the intestine into the blood. The leakage of LPSs into the blood activates the nonspecific inflammation affecting the metabolism of the liver, adipose, and muscle tissue. In addition, these endotoxins can alter the activity of the small intestine nervous system and 
the gut-brain axis through the vagal nerve, affecting the appetite regulation. This concept of metabolic endotoxemia (an increase in plasma LPSs) is considered one of the triggers leading to the development of meta-inflammation and IR [48]. Eating a high-fat diet increases the production of Gram-negative bacteria in the intestine and the uptake of LPSs from the intestine into the bloodstream. LPS production correlates with the content of lipids in food. Both lipids and LPSs produced by Gram-negative bacteria in the microbiota bind scavenger receptor class B type I (SR-BI), which enhances the incorporation of LPSs into chylomicrons. These complexes are transported through the lymph into the bloodstream, where LPSs are transferred to other lipoproteins, mainly high-density lipoproteins (HDLs) by translocases. LPSs bound by SR-BI enhance lipoprotein transcytosis across the endothelial barrier and endocytosis in adipocytes [10]. Adipocytes, which absorb the most LPS-rich lipoproteins, become large. In addition, macrophages in adipose tissue internalize LPS lipoproteins, which can change their phenotype from M2 to M1. Large adipocytes are more metabolically active and uptake more LPSs than small adipocytes. LPSs within adipocytes activate caspase- $4 / 5 / 11$, which can induce a highly inflammatory type of programmed cell death (pyroptosis). Adipocyte death occurs when their size grows to such an extent that the intracellular concentration of LPSs initiates pyroptosis. Thus, the hypertrophy, inflammation, and death of adipocytes are stimulated through the mechanisms that cause the excessive production of LPSs by the intestinal microbiota [46]. This means that the diet-induced disturbances in the composition of the intestinal microbiome contribute to the development of a hypertrophic variant of obesity and the occurrence of chronic inflammation. As a result, developing chronic inflammation can lead to metabolic dysregulation in many organs (the intestine, the adipose tissue, the muscles, the liver, and the brain), in particular, through the modulation of the innate and adaptive immune system [59].

Another mechanism for the induction of not only adipose tissue inflammation, but also inflammation of other organs is a change in the effects of specific metabolites produced by intestinal bacteria, primarily short-chain fatty acids (SCFAs) (lactate, butyrate, propionate, acetate, and succinate). These metabolites can affect the local and the systemic immune response and modulate metabolic homeostasis [60]. Enteroendocrine cells (EECs) producing glucagon-like peptide-1 (GLP-1), peptide YY (PYY), and glucagon-like peptide-2 and the endocannabinoid system have also been demonstrated to control the intestinal permeability and to be involved in metabolic endotoxemia and altered signal transmission from the GIT to the central nervous system. The digestive tract interacts with the central nervous system, transmitting the information about the nutritional status through a variety of mechanisms, including EECs, the vagus nerve system, and the enteric nervous system. SCFAs can modulate the secretion of these hormones and neurotransmitters [61,62]. The vagus nerve is involved in appetite regulation and gastrointestinal motility and has anti-inflammatory properties [63]. Mechanoreceptors of the GIT, hormones (ghrelin, PYY, cholecystokinin, GLP-1) secreted by the EECs and microbial metabolites (SCFAs) are involved in its activation (ghrelin and PYY inhibit it; cholecystokinin and GLP-1 activate it) [64]. In addition, SCFAs themselves are the signaling molecules that bind to G-proteincoupled receptors (GPRs) GPR43 and GPR41 and modulate satiety and may increase energy expenditure [65]. They also play a role in central nervous system (CNS) inflammation [66]. These changes, in turn, contribute to the impairment of incretin production. Most likely the signaling alterations from the GIT, through both a change in the production of microbiota metabolites (SCFAs) and the modification of the hormone production in the GIT, lead to the reprogramming of the deposition pathway in the SAT from hyperplasia (which shows metabolically healthy obesity) to hypertrophy of adipocytes and increased fat accumulation in visceral adipose tissue (VAT) with the formation of adipose tissue ectopia and changes in the functions of organ adipocytes. Glucose-dependent insulinotropic peptide (GIP), which is responsible for the deposition of lipids in the SAT under the normal conditions, is the likely key factor of the reprogramming [67]. The role of GIP in the regulation of energy accumulation in adipose tissue and the development of metabolic disorders was confirmed by the fact that GIP affects all the key tissues that are important for the control of glucose 
and lipid homeostasis, stimulates insulin biosynthesis and secretion, and increases the viability of islet cells. GIP regulates lipid metabolism (modulating lipolysis and lipogenesis depending on insulin level) directly through its receptor on adipocytes. In the fasting state GIP stimulates glucagon secretion and lipolysis in the SAT, and in the postprandial state (an increase in glucose and insulin levels) it inhibits glucagon secretion, stimulates insulin secretion and adipogenesis in the SAT, and increases the intake of triglycerides (TGs) in the SAT. Normally, GIP is responsible for the deposition of excess energy in the SAT; consequently, an impairment of GIP signaling can contribute to changing the fat accumulation from the SAT to the VAT.

Thus, a change in the composition and functioning of the microbiome through the mechanisms, including a change in the production of active metabolites-in particular, SCFAs-leads to a change in intestinal permeability, the production of incretins and other hormones of the GIT. The impairment of their signaling to a large extent contributes to a change in fat accumulation from the SAT to the VAT, from hyperplasia to hypertrophy, the development of IR in adipose tissue, chronic inflammation, and OS. In recent decades, five stages have been conventionally distinguished in the chronology of type 2 DM development. The earliest stages, which are characterized by the absence of carbohydrate metabolism disorders, are the 1st stage (latent) and the 2nd stage (transient) [68]. They are characterized by hyperinsulinemia, IR, and activation of the renin-angiotensin-aldosterone system both systemically and in the pancreas islets. Pathophysiologically, this comprises the islet redox stress (oxidative and nitrosative stress), free-radical polymerization of islet amyloid polypeptide monomers, $\beta$-cell endoplasmic reticulum (ER) stress, and unfolded protein response (UPR) stress. At the 2 nd stage, the processes of amyloidosis and fibrosis of $\beta$-cells join [69]. They become the basis for the development of further carbohydrate metabolism disorders. This means that the prevention of IR development should be considered the earliest option for the prevention of all further pathological changes.

\section{Metformin Role in Prevention and Correction of the Changes Associated with the Fat-Rich Food and High Glycemic Index Products, Effects on the Structure of the Microbiota}

In recent years, the focus on the key effector organs has moved from the liver to the GIT. The most significant argument in favor of the GIT is the fact that intravenous injection of metformin does not have glucose-lowering effects [70,71], and its concentration in the intestinal mucosa is 30-300 times higher than in plasma [72]. The fact that metformin positively affects the GIT, even if the pathological stereotype of the nutrition persists, is extremely important. Today, one way of realizing the effects of metformin is through the strengthening of incretin actions (Table 1) [73]. The mechanisms of metformin interaction with the intestinal microbiome include not only the regulation of glucose metabolism, but also an elevation in the production of SCFAs, an increase in the intestinal permeability for LPSs, the modulation of the immune response, and interaction with bile acids [73] (Table 1).

Bile acids (cholic acid and chenodeoxycholic acid) are another significant recipient of metformin's effects. Bile acids are synthesized from cholesterol in the liver and are secreted into the intestine, where they are converted into secondary bile acids such as deoxycholic acid and lithocholic acid with the participation of the enzymes and the intestinal microbiota (Table 1). They play an essential role in the metabolism of glucose and lipids [74] via a number of metabolic pathways, binding to several intracellular nuclear receptors, including the farnesoid X receptor (FXR), pregnane X receptor (PXR), and G-protein-coupled receptors (GPRs) [75]. The results of a meta-analysis of metagenomic data are a significant argument supporting the importance of metformin's effects on the microbiota. This meta-analysis showed that the gut microbiome was less abundant in patients with type $2 \mathrm{DM}$ without metformin treatment, and its diversity recovered almost to the level of healthy people in the metformin-treated control group [76].

Thus, the effects of metformin on the GIT microbiota and the inhibition of the harmful effects of disordered dietary stereotypes (fat-rich and high glycemic index foods), both on the composition of the microbiota and on the subsequent systemic effects, are the earliest 
in the prevention of the development of metabolic disorders leading to obesity, IR, type $2 \mathrm{DM}$, and its CV complications. Experimentally, treatment with metformin for 14 weeks in mice was shown to significantly prevent high-fat diet-induced obesity and associated inflammatory response by increasing the expression of fibroblast growth factor 21 (FGF-21), which is a key metabolic hormone improving lipolysis in brown adipose tissue (BAT) to prevent fat accumulation [77]. In addition, metformin can prevent obesity in mice by increasing the metabolic activity of BAT [78].

The effects of metformin on the intestinal permeability, LPS entry into the bloodstream, modulation of the gut-CNS axis, and production of SCFAs and bile acids can prevent (and if not completely, then significantly reduce) the severity of pathological reprogramming of fat storage from hyperplastic adipocytes of the SAT into hypertrophic adipocytes of the VAT, the development of meta-inflammation, and IR.

The recipients of metformin's effects in patients with prediabetes and diabetes have been described in numerous reviews and are not a new topic. The mechanisms of metformin's effect on the cardiovascular system deserve more attention. Although they are not a new topic, but their structuring and refinement considering the new data, will undoubtedly be useful.

DM has long been designated as the equivalent of cardiovascular pathology, and indeed it sharply increases the risk of cardiovascular death from two complexes of cardiovascular problems: atherosclerotic CVD and cardiorenal diseases (heart failure (HF) and chronic kidney disease (CKD)). The risk of ischemic heart disease is increased 3.77 $(1.74 ; 8.17)$ times by diabetes [79]; half of type 2 DM patients have CKD [80], and 15\% have chronic HF [81], which is 2.5 times more than in people without type 2 DM [82].

These two sets of problems are associated with the different mechanisms and develop at different stages of the cardiometabolic continuum. There is a growing body of evidence demonstrating that obesity plays a leading role among the factors associated with the early development of HF and CKD. Thus, the ARIC study analyzed the relationship between body mass index (BMI) and main CVD in linear models adjusted for other risk factors (age, sex, smoking, alcohol, physical activity, the presence of DM, the level of blood pressure, lipids, and glomerular filtration rate (GFR)). The most pronounced association with BMI was shown for the risk of HF $[83,84]$. Without a doubt, HF can be an outcome of atherosclerotic CVD, but this phenotype is formed much later and is associated with a complicated course of ischemic heart disease (myocardial infarction (MI)), a longer duration of DM, and insulin therapy [85,86].

The mechanisms that are the cornerstone of these processes are actively being studied. The violation of autophagy processes is among them. Its activation again may occur in the 1st-2nd stages of the formation of DM, before the development of dysglycemia [87] (Table 2).

Table 2. Key effects of metformin at different stages of the cardiometabolic and cardiorenal continuum.

\begin{tabular}{|c|c|c|c|}
\hline Stage & Key Pathogenetic Disturbances & Key Effects of Metformin & References \\
\hline \multirow{2}{*}{$\begin{array}{l}\text { Development of HFpEF and } \\
\text { CKD in patients with } \\
\text { metabolically unhealthy obesity, } \\
\text { prediabetes, and early diabetes }\end{array}$} & $\begin{array}{l}\text { excess nutrients } \rightarrow \text { functional overload of } \\
\text { mitochondria } \rightarrow \text { violation of autophagy } \\
\text { processes } \rightarrow \uparrow \text { ROS } \rightarrow \text { toxic effects on cell } \\
\text { structures and } \downarrow \text { SIRT1/PGC-1a/FGF21 and } \\
\downarrow \text { AMPK }\end{array}$ & $\begin{array}{l}\text { activation of AMPK } \rightarrow \text { AMPK-mediated } \\
\text { inactivation of mTOR } \rightarrow \uparrow \text { mitochondrial } \\
\text { biogenesis and aerobic glycolysis } \rightarrow \\
\text { improvement of autophagy processes } \rightarrow \uparrow \\
\text { collagen turnover through autophagy }\end{array}$ & [88] \\
\hline & $\begin{array}{l}\text { hyperinsulinemia and IR } \rightarrow \uparrow \text { activity of } \\
\text { NHE1 in the heart and NHE3 activity in the } \\
\text { kidney } \rightarrow \uparrow \text { circulating blood volume and } \\
\text { sodium retention } \rightarrow \uparrow \text { LV filling pressure }\end{array}$ & $\begin{array}{l}\downarrow \text { circulating insulin levels and improvement of } \\
\text { insulin sensitivity through multiple } \\
\text { mechanisms } \\
\text { considering that hyperinsulinemia is a key } \\
\text { factor in increasing the activity of NHE1 and } \\
\text { NHE3, it can have at least indirect effects on } \\
\text { these mechanisms }\end{array}$ & {$[89,90]$} \\
\hline
\end{tabular}


Table 2. Cont.

\begin{tabular}{|c|c|c|c|}
\hline Stage & Key Pathogenetic Disturbances & Key Effects of Metformin & References \\
\hline & $\begin{array}{l}\uparrow \text { volume and change in characteristics of } \\
\text { epicardial adipose tissue (a change in the } \\
\text { phenotype of adipocytes from brown to } \\
\text { white), } \uparrow \text { production of pro-inflammatory } \\
\text { adipokines, the development of } \\
\text { inflammation and myocardial fibrosis }\end{array}$ & $\begin{array}{l}\downarrow \text { production of pro-inflammatory cytokines } \\
\text { and anti-fibrotic effect }\end{array}$ & {$[91-94]$} \\
\hline & & $\begin{array}{l}\text { inhibition of TGF- } \beta \text { production } \rightarrow \downarrow \\
\text { phosphorylation and nuclear translocation of } \\
\text { Smad } 2 / 3 \text { and preventing the transcriptional } \\
\text { activation of fibrogenic target genes such as } \\
\text { collagen } 1 \alpha 1 \text { (colla1) and collagen } 3 \alpha 1 \text { (col3a1) }\end{array}$ & \\
\hline & $\begin{array}{l}\text { metabolic unhealthy obesity } \rightarrow \\
\text { hyperinsulinemia and lipotoxicity } \rightarrow \\
\text { activation of systemic inflammation and } \\
\text { formation of AGEs } \rightarrow \downarrow \text { NO synthesis and } \\
\uparrow \text { ROS production } \rightarrow \text { induction of oxidative } \\
\text { stress and the accumulation of peroxidation } \\
\text { products, } \downarrow \text { activity of PKG in } \\
\text { cardiomyocytes } \rightarrow \text { LVH }\end{array}$ & $\begin{array}{l}\text { modification of integrin expression } \rightarrow \downarrow \\
\text { phosphorylation of ERK } 1 / 2 \text { and improving } \\
\text { the expression of extra cellular matrix } \\
\text { components, inhibition of the expression of } \\
\text { TGF- } \beta 1 \text {-induced monocytic chemotactic } \\
\text { protein-1, reduction in the activity of p38 } \\
\text { MAPK and JNK, block of the effect of TGF- } \beta 1 \\
\text { on phosphorylation of GSK-3 } \beta \text { and nuclear } \\
\text { translocation of } \beta \text {-catenin } \rightarrow \text { inhibiting the } \\
\text { transcription of various fibrogenic genes, } \\
\text { including fibronectin }\end{array}$ & [95-107] \\
\hline & $\begin{array}{l}\text { oxidative stress activation } \rightarrow \text { mitochondrial } \\
\text { dysfunction } \rightarrow \downarrow \text { ATP production, } \downarrow \text { calcium } \\
\text { release from the sarcoplasmic reticulum, } \downarrow \\
\text { SERCA activity and } \downarrow \text { sensitivity of } \\
\text { myofibrils to calcium, } \downarrow \text { activity of GTP4 } \\
\text { violation of the AGE/RAGE ratio } \rightarrow \uparrow \\
\text { TGF- } \beta \text { production } \rightarrow \text { induction of fibrosis }\end{array}$ & $\begin{array}{l}\text { acceleration of the fibrosis resolution: } \\
\text { - } \quad \text { reduction in the level of Gal-3 in the } \\
\text { systemic circulation, in adipocytes and } \\
\text { monocytes in patients with type } 2 \text { DM } \\
\downarrow \text { NOX4 activity, mitochondrial } \\
\text { oxidative stress and inhibited activity of } \\
\text { PKC } \alpha \text { and mTOR-S6K signaling } \\
\text { pathway } \rightarrow \downarrow \text { expression of Gal-3 } \\
\text { secreted by cardiomyocytes in mice, } \downarrow \\
\text { Gal-3 in bloodstream, adipocytes, } \\
\text { monocytes } \rightarrow \downarrow \text { activation of cardiac } \\
\text { fibroblasts } \rightarrow \downarrow \text { myocardial fibrosis } \rightarrow \\
\text { improvement in cardiac fibrosis after } \\
\text { myocardial infarction in mice }\end{array}$ & \\
\hline
\end{tabular}

hyperuricemia $\rightarrow$ inhibition of AMPK

activity $\rightarrow$ induction of oxidative stress

hyperuricemia $\rightarrow$ IRS/PI3K/Akt pathway

$\rightarrow$ induction of IR in cardiomyocytes,

adipocytes, muscles and liver

hyperuricemia $\rightarrow$ inhibition of insulin signaling and induction of IR of cardiomyocytes in vitro and in vivo

hyperuricemia $\rightarrow$ reduction in the speed of GLUT4 movement $\rightarrow$ inhibition of insulin-induced glucose uptake in cardiomyocytes $\rightarrow \uparrow$ ROS production

hyperuricemia is characterized by $\uparrow$ inflammatory markers (CRP), fibrosis markers - Gal-3 and CITP activation of AMPK and its phosphorylation $\rightarrow$ reduction in the severity of hyperuricemia and blocking of its negative effects $\rightarrow$ protection against hyperuricemia-induced IR in cardiomyocytes and skeletal muscles and associated pathological processes, including fibrogenesis ( $\uparrow$ levels of Gal-3, types 1 and 3 procollagen) 
Table 2. Cont.

\begin{tabular}{|c|c|c|c|}
\hline Stage & Key Pathogenetic Disturbances & Key Effects of Metformin & References \\
\hline \multirow[t]{6}{*}{$\begin{array}{l}\text { Development and progression } \\
\text { of atherosclerosis in type } 2 \mathrm{DM}\end{array}$} & $\begin{array}{l}\text { changes in the activity of a number of genes } \\
\text { and transcription factors, for example, } \\
\text { NF- } \mathrm{B} \text {, and molecules, such as AGE, capable } \\
\text { of modifying components of the } \\
\text { extracellular matrix } \rightarrow \text { ED } \\
\text { activation of the RAGE in vasculature in DM } \\
\rightarrow \text { atherogenesis } \\
\text { hyperglycemia } \rightarrow \text { transcription factor NF- } \mathrm{B} \\
\rightarrow \text { development of ED, modulation of the } \\
\text { expression of a number of microRNAs (in } \\
\text { particular, miR-126, }-21, \text { and miR-146a-5p) } \\
\text { involved in atherogenesis, and PKC } \\
\text { hyperactivation } \rightarrow \uparrow \text { production of } \\
\text { superoxide anions and VEGF, } \downarrow \text { NO } \\
\text { production, } \uparrow \text { activity of the polyol pathway } \\
\rightarrow \text { consumption of NADPH enhances } \\
\text { intracellular oxidative stress } \\
\text { hyperglycemia } \rightarrow \text { impairment of vascular } \\
\text { permeability and involvement of leukocytes } \\
\text { in inflammatory reactions } \rightarrow \text { changes in EC } \\
\text { morphology and density, changes in the } \\
\text { functional properties of EC } \rightarrow \text { deterioration } \\
\text { in the bioavailability of NO, modulation of } \\
\text { vascular tone, a violation of the ratio of } \\
\text { vasodilators (NO and PGI } 2 \text { ) and } \\
\text { vasoconstrictors (ET-1) }\end{array}$ & $\begin{array}{l}\text { activation of AMPK } \rightarrow \text { delay of endothelial } \\
\text { and vascular aging, } \uparrow \text { rate of oxygen } \\
\text { consumption by mitochondria } \\
\text { AMPK-dependent } \uparrow \text { H3K } 79 \text { me } 3 \rightarrow \\
\text { SIRT1-DOT1L } \rightarrow \text { hTERT (enzyme involved in } \\
\text { adding telomere repeats to the ends of the } \\
\text { chromosome, a process that modulates } \\
\text { vascular senescence) } \rightarrow \text { reduction of stiffness } \\
\text { of the vascular wall and deceleration of } \\
\text { vascular aging } \\
\text { AMPK-dependent H3K79me } \rightarrow \uparrow \text { SIRT3 } \rightarrow \\
\text { improvement of mitochondrial } \\
\text { biogenetics / function and delay of endothelial } \\
\text { aging } \\
\text { in patients with prediabetes: } \\
\uparrow \text { SIRT1 expression, } \downarrow \text { p } 70 S 6 \mathrm{~K} \text { phosphorylation } \\
\text { and improvement of plasma N-glycan profile } \\
\rightarrow \uparrow \text { telomere length in mononuclear cells, } \\
\text { which, as previously shown in the experiment, } \\
\text { regulate lifespan }\end{array}$ & [113-117] \\
\hline & $\begin{array}{l}\text { hyperglycemia } \rightarrow \text { disruption in the } \\
\text { functioning of the insulin receptor, } \\
\text { activation of transduction in favor of } \\
\text { proatherogenic effects instead of } \\
\text { antiatherogenic ones } \rightarrow \text { activation of } \\
\text { atherogenesis }\end{array}$ & & \multirow{4}{*}[118,119]{} \\
\hline & $\begin{array}{l}\text { insulin receptor } \rightarrow \text { activation of } \\
\text { PI3K/protein kinase B (Akt)/eNOS pathway } \\
\text { in the endothelium } \rightarrow \text { phosphorylation of } \\
\text { eNOS at Ser } 1177 \rightarrow \text { activation of } \\
\text { phosphorylation of SHC, activating MAPK } \\
\text { pathway } \rightarrow \uparrow \text { ET- } 1 \text { expression, } \downarrow \text { NO } \\
\text { availability } \rightarrow \text { impairment of NO functions: } \\
\text { maintaining vascular homeostasis, } \\
\text { protecting against the development of } \\
\text { ischemic heart disease, } \uparrow \text { mitochondrial } \\
\text { organization by } \uparrow A M P K \text { activation and } \\
\text { PGC-1a expression }\end{array}$ & $\begin{array}{l}\text { AMPK } \rightarrow \text { inhibition of SREBP-1 and ChREBP } \\
\rightarrow \text { reduction in the expression of several genes } \\
\text { of lipogenesis } \\
\text { inhibiting the entry of lipids into the vascular } \\
\text { wall } \rightarrow \text { prevention of plaque formation } \\
\text { AMPK } \rightarrow \text { phosphorylation of eNOS at Ser } \\
1179 \rightarrow \uparrow \text { bioavailability of NO } \\
\text { experimental studies: affecting to } \\
\text { hematopoietic AMPK } \rightarrow \text { direct inhibition of } \\
\text { atherogenesis }\end{array}$ & \\
\hline & $\begin{array}{l}\text { hyperglycemia } \rightarrow \text { deficiency of } \\
\text { proteoglycans, which inhibit the binding of } \\
\text { monocytes to the subendothelial region. }\end{array}$ & & \\
\hline & $\begin{array}{l}\text { oxLDLs } \rightarrow \text { activation of macrophages } \rightarrow \\
\text { rapid progression of atherogenesis }\end{array}$ & & \\
\hline & $\begin{array}{l}\text { hyperglycemia } \rightarrow \text { oxidative stress, oxidation } \\
\text { of LDL, } \uparrow \text { activity of the hexosamine } \\
\text { pathway } \rightarrow \text { fructose- } 6 \text {-phosphate, instead of } \\
\text { being included in glycolysis, becomes a } \\
\text { substrate for GFAT } \rightarrow \text { TGF- } \beta \text { transcription } \\
\text { and fibrotic processes }\end{array}$ & $\begin{array}{l}\text { inhibition of glycerophosphate transporter } \\
\text { enzyme mGPDH } \rightarrow \text { prevention of the use of } \\
\text { glycerol as a substrate for gluconeogenesis }\end{array}$ & [120] \\
\hline
\end{tabular}


Table 2. Cont.

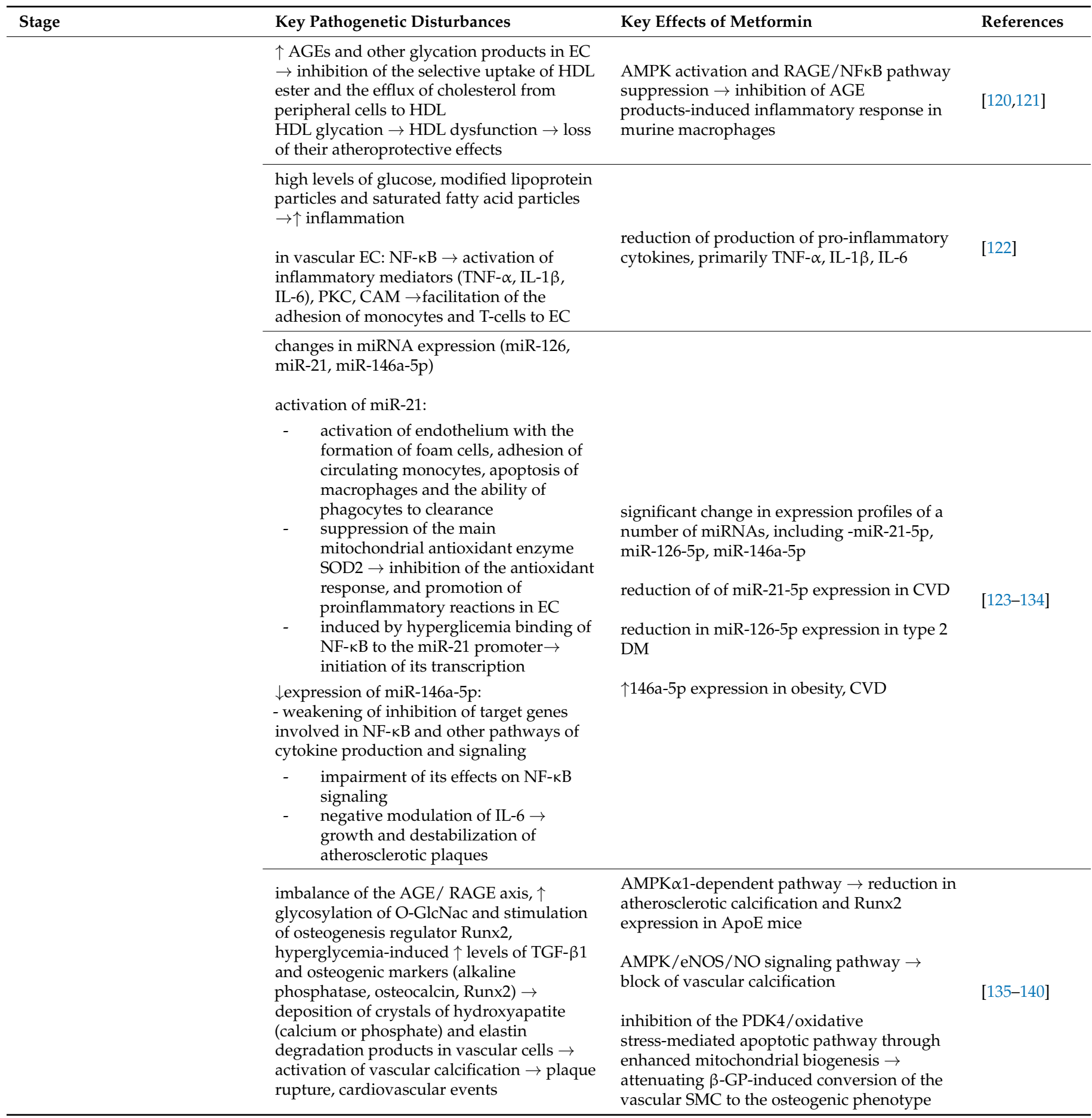


Table 2. Cont.

\begin{tabular}{|c|c|c|c|}
\hline \multirow[t]{2}{*}{ Stage } & Key Pathogenetic Disturbances & Key Effects of Metformin & References \\
\hline & $\begin{array}{l}\text { ATF } 1 \rightarrow \text { determination of macrophage } \\
\text { Mhem phenotype } \rightarrow \text { intra-plaque } \\
\text { hemorrhages } \rightarrow \text { instability of atherosclerotic } \\
\text { plaques }\end{array}$ & $\begin{array}{l}\text { AMPK } \rightarrow \text { inhibition of Mhem macrophages } \\
\text { and foam cell formation }\end{array}$ & {$[88,141,142]$} \\
\hline & 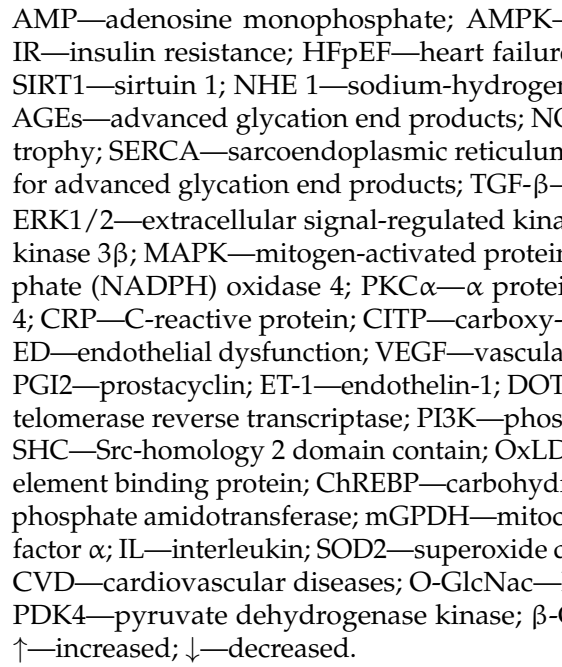 & 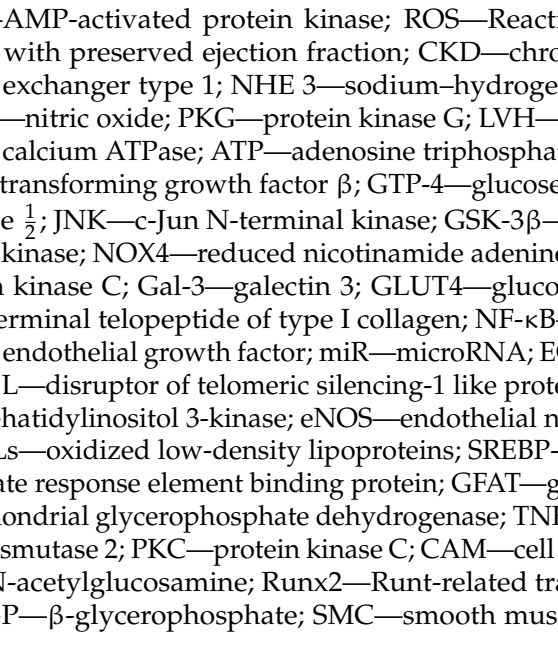 & $\begin{array}{l}\text { oxygen species; } \\
\text { kidney disease; } \\
\text { xchanger type 3; } \\
\text { t ventricle hyper- } \\
\text { RAGE-receptor } \\
\text { insport protein 4; } \\
\text { ycogen synthase } \\
\text { nucleotide phos- } \\
\text { transporter type } \\
\text { uclear factor kB; } \\
\text {-endothelial cells; } \\
\text { hTERT-human } \\
\text { c oxide synthase; } \\
\text { sterol regulatory } \\
\text { amine fructose-6- } \\
\text {-tumor necrosis } \\
\text { tesion molecules; } \\
\text { cription factor 2; } \\
\text { cells; } \rightarrow \text {-affect; }\end{array}$ \\
\hline
\end{tabular}

The state of excess nutrients is characterized by the suppression of autophagy, the process responsible for the destruction of damaged organelles. Glucose and lipid metabolites such as diacylglycerol (DAG) inhibit the formation of autophagic vacuoles and their fusion with lysosomes for lysis. The suppression of autophagy leads to the accumulation of damaged organelles, which are the main substrate for oxidative stress (OS) and ER stress [143].

The general mechanisms of the formation of myocardial dysfunction and HF in IR and type $2 \mathrm{DM}$ are based on hyperinsulinemia. Today hyperinsulinemia is considered to be the pivotal trigger for the development of HF in obesity and type $2 \mathrm{DM}$. The key and universal mechanism for any HF phenotype is an increase in the activity of sodiumhydrogen exchangers of types 1 and 3 (NHE1 and NHE3) [144] (Table 2). The NHE1 isoform is expressed in all organs, but it predominates in the heart, where it regulates cell volume and $\mathrm{pH}$, and NHE3 isoform expression is limited to the apical surface of the renal tubules and epithelial cells of the GIT, where it provides sodium reabsorption. Hyperinsulinemia increases NHE1 and NHE3 activity, and thus, type 2 DM may contribute to the development of both HF with reduced ejection fraction (HFrEF) and HF with preserved ejection fraction (HFpEF) [89].

Hyperinsulinemic, metabolically unhealthy obesity is characterized by the accumulation of not only visceral but also ectopic fat, which is involved in the induction of myocardial inflammation, microcirculation dysfunction, and fibrosis $[145,146]$ (Table 2).

In healthy people, epicardial adipose tissue is BAT; however, under the conditions of excess fatty acids, lipotoxicity, and imbalance of adipokines (hyperleptinemia and leptin resistance, excess tumor necrosis factor $\alpha$, interleukin- 6 and resistin, adiponectin deficiency), a rise in cell volume and the redifferentiation of epicardial adipose tissue cells occurs, wherein it acquires the properties of WAT. Considering the conjoint microcirculatory system of the epicardium and myocardium, when metabolic functions and the secretory profile of epicardial adipose tissue adipocytes change, the myocardium is exposed to the produced pro-inflammatory cytokines being involved in the processes of inflammation and fibrosis [147]. The significance of these relationships is supported by the fact that the volume of epicardial adipose tissue is closely related to the severity of coronary capillary dysfunction, myocardial fibrosis, and LV hypertrophy [147]. Hyperleptinemia and leptin resistance, which are formed, such as hyperinsulinemia/IR, at the metabolically unhealthy 
obesity stage, contribute significantly to the described changes, exacerbating the disorders induced by hyperinsulinemia [91]. The severity of hyperleptinemia correlates with the volume of epicardial adipose tissue, promotes sodium retention through the stimulation of aldosterone secretion, enhances myocardial and vascular fibrosis, and, accordingly, relaxation disorders, and negatively affects calcium metabolism in the myocardium [94,147].

Hyperuricemia is among the disorders involved in the early pathogenesis of obesity and metabolic syndrome. Hyperuricemia has been identified not only as a risk factor for gout, but also as a contributing factor to impaired glucose metabolism, dyslipidemia, and hypertension. High uric acid levels are strongly associated with cardiovascular disease, including coronary artery disease and HF $[148,149]$.

Hyperuricemia has been demonstrated to be an inducer of oxidative stress in many cells [150], including hepatocytes and pancreatic endocrinocytes [112] and kidneys cells [151] (Table 2).

Hyperuricemia is characterized by an increase in inflammation markers such as Creactive protein (CRP), fibrosis markers such as galectin-3 (Gal-3) and carboxy-terminal telopeptide of type I collagen (CITP). In general, a high level of these markers as well as procollagen-3, according to a number of studies, is specific for patients with obesity and type $2 \mathrm{DM}$ and is a predictor of the development of $\mathrm{CV}$ disorders (HF, atrial fibrillation, progression of atherogenesis).

\section{Key Mechanisms for the Development of CKD and HFpEF}

$\mathrm{CKD}$ and HFpEF form a cardiorenal complex that begins long before the development of DM and is associated with IR and hyperinsulinemia. This has been proven by numerous experimental and clinical data [152-155]. In fact, hyperinsulinemic obesity and type 2 $\mathrm{DM}$ are states of chronic excess energy, in which the Akt/mTORC1 pathway is activated and the suppression of sirtuin 1 (SIRT1), which is activated by caloric restriction and the suppression of its descending executive elements-peroxisome proliferator-activated receptor gamma coactivator 1a (PGC-1a), fibroblast growth factor 21 (FGF-21), and adenosine monophosphate-activated protein kinase (AMPK)—occurs [156].

During embryogenesis, the activation of Akt/mTORC1 promotes the growth and development of the heart; however, in adults, the activation of this pathway leads to disruption of the autophagy process, and hyperactivity from hyperinsulinemia causes HF, while suppression of Akt signaling reduces the severity of hypertrophy and fibrosis of the myocardium and delays the development of HF [156]. AMPK in the myocardium counteracts Akt/mTORC1. As a result, type $2 \mathrm{DM}$ is characterized by the decreased activation of SIRT1/PGC-1a/FGF21 and AMPK, as well as by autophagy suppression. These disorders precisely distinguish hyperinsulinemic states, since insulin directly suppresses autophagy through the inhibition of SIRT1 and activates Akt/mTORC1 signaling [157,158].

The mechanisms of lipotoxicity include an increase in the concentration and oxidation of fatty acids (FAs) in the myocardium because of the growth in their uptake. With the activity of peroxisome proliferator-activated receptor- $\alpha$ (PPAR- $\alpha$ ), the accumulation of TG and DAG in the myocardium increases. The uptake and the oxidation of glucose, on the contrary, are reduced owing to a decrease in the activity of the glucose transport protein (GTP)-4 (Table 2). An important role in the development of contractile disorders is played by a decreased Ca2 + turnover in the cardiomyocytes [159]. Increased activity of protein kinase $\mathrm{C}(\mathrm{PKC})$ reduces the availability of nitric oxide and causes an increase in endothelin1 production and connective tissue growth factor expression. An elevated AGE formation with a violation of the AGE/receptor for advanced glycation end products (RAGE) ratio is accompanied by a reduced production of transforming growth factor $\beta$ (TGF- $\beta$ ) and of ROS. The activation of the renin-angiotensin-aldosterone system accompanies these changes.

Thus, the predominant mechanism for the progression of HFpEF in DM, primarily against the background of obesity and metabolic syndrome, is characterized by the induction and the expansion of inflammation (systemic and in epicardial adipose tissue). 
Inflammation causes mediated by pro-inflammatory cytokines microvascular dysfunction, oxidative stress, and myocardial fibrosis. Hyperuricemia and changes in microbiome composition make important contributions to the induction of inflammation. We have already considered the change in the characteristics of the microbiome as the first step in a cascade of inflammatory changes and changes in the characteristics of adipose tissue (the transition of hyperplasia to hypertrophy), which form its metabolically unhealthy phenotype. As described in detail above, hyperinsulinemia and hyperuricemia, typical for obesity and metabolic syndrome chronic inflammation, through transforming growth factor- $\beta$ (TGF- $\beta$ ), AGE and ROS-dependent pathways, induce the development of myocardial, vascular, and renal fibrosis. These changes are key to the progression of HFpEF and CKD.

\section{Pathogenetic Features of Atherosclerosis Development in IR and Type 2 DM}

Atherosclerosis is a major diabetes complication with several causative factors. Vascular endothelial dysfunction (ED) characterizes both DM and atherosclerosis. Hyperglycemia, in addition to lipotoxicity and hyperinsulinemia, plays a significant role in the activation of ED, inflammation of the vascular wall, and atherogenesis. The crucial mechanisms of ED in vascular injury and atherogenesis are presented in Table 2 [113-115,118].

At high glucose levels, the proatherogenic pathway is activated to a greater extent (Table 2) $[119,120]$. Vascular inflammation is a key change leading to atherosclerosis, and DM characterized by an increase in circulating markers of inflammation and expression of monocytic genes of pro-inflammatory mediators worsens it [122]. Monocytes migrating into the endothelium give rise to the conversion of foam cells with an accumulation of lipids and the formation of atherosclerotic plaques. The resulting atherosclerosis underlies a number of atherosclerotic CVDs.

Hyperglycemia alters the expression of a number of miRNAs that affect both vascular dysfunction and inflammatory conditions [123]. They are miR-126, miR-21, and miR-146a$5 \mathrm{p}$. These changes are associated with changes in NF-kB activity. Activation of miR-21, according to some authors, may be a critical event linking diabetes and the development of atherosclerosis (Table 2). miR-146a-5p has been identified as a negative regulator of NF-кB [128,160] (Table 2).

Finally, vascular calcification is among the key features of vascular lesion in DM, which is a severe, irreversible change and typical for people with atherosclerosis associated with diabetes and CKD (Table 2). An imbalance in the AGE/RAGE axis in hyperglycemia promotes vascular calcification, exacerbating preexisting atherosclerotic damage with more severe changes. Previous studies have shown the association between plaque formation in the carotid arteries in DM, increased glycosylation of $\mathrm{N}$-acetylglucosamine (O-GlcNac), and stimulation of the osteogenesis regulator Runt-related transcription factor 2 (Runx2) [135]. Atherosclerosis is characterized by intimal calcification, but DM can induce medial calcification even in the absence of atherosclerosis (Table 2). In addition, miR-126, miR-21, and $\mathrm{miR}-146 \mathrm{a}$ are common in diseases that play a regulatory role in vascular calcification of the media and the transdifferentiation of vascular smooth muscle cells into osteogenic-like cells [114]. The combination of intimal and medial calcification is observed mainly in peripheral medium caliber arteries and associated with the progression of atherosclerosis and serious complications from cerebrovascular vessels (dementia, stroke), renal vessels (chronic renal failure), and lower extremities (critical ischemia).

\section{Metformin's Effects on the Inhibition of the Mechanisms of Cardiorenal Continuum Formation-HFpEF and CKD}

Above, we identified the main stages in the formation of HFpEF and CKD through a pathological lifestyle and an imbalance in the composition of the microbiota into metabolically unhealthy obesity, hyperinsulinemia, and IR, with the progression of chronic inflammation, oxidative stress, and the development of fibrosis. The mechanisms of metformin's influence on these processes were also largely, but not completely, discussed above. As discussed in the recent review, metformin blocks the development and the progression of 
both HFpEF and HFrEF through a variety of complex pleiotropic effects, in particular, by its direct effects on myocardial structure and function, allowing the maintenance of normal LV morphology and functional activity [161]. These mechanisms are described in detail in this review, so we will not dwell on them here.

Hyperuricemia has been identified as an important factor in oxidative stress and activation of fibrogenesis in the myocardium and kidneys. Metformin in experimental rat models decreased serum uric acid levels and, through cyclic adenosine monophosphate (AMP)-dependent protein kinase, reduced the negative effects of hyperuricemia [108,162]. Metformin can reduce the severity of hyperuricemia by activating AMPK and its phosphorylation and protecting against IR caused by hyperuricemia in cardiomyocytes, skeletal muscles [111], and associated pathological processes, including increased fibrogenesis (elevated level of Gal-3, procollagen types 1 and 3).

Metformin, as a powerful AMPK activator, is a promising drug for reducing or reversing the fibrosis. Numerous studies examining the mechanisms of metformin on fibrosis have shown that it mainly exerts an anti-fibrotic effect, affecting the signaling pathway of TGF- $\beta$, cellular metabolism, and oxidative stress, including that induced by hyperuricemia. Metformin has a direct anti-fibrotic effect (Table 2), inhibiting the production of TGF- $\beta 1[88,95-97,99-101,103]$.

In a hybrid study involving in vitro experiments, animal models, and clinical evaluation of patients, its production was shown to be higher in the VAT than in the SAT and in circulation. Gal-3 showed a positive BMI-dependent correlation with leptin, resistin, interleukin-6, and age [163]. In patients with type 2 DM, Gal-3 was elevated in serum. It positively correlated with the level of C-reactive protein. Metformin treatment was associated with lower levels of Gal-3 in the systemic circulation in patients with type 2 DM (Table 2). The ability of this drug to reduce the severity of oxidative stress and the formation of AGEs [164], which, in turn, induce the expression of Gal-3, is considered as a possible mechanism for reducing the level of Gal-3 during metformin therapy. The contribution of AMPK activity modulation is also being considered. Oxidative stress is a central mechanism involved in fibrotic progression. AMPK is the oxidative stress suppressor and is critical for regulating ROS production. Metformin, as an AMPK activator, reduces ROS production and suppresses oxidative stress [99,103,107,165-167].

The cardioprotective effects of metformin have been largely determined by its ability to decrease the severity of cardiac fibrosis caused by pressure overload, MI, and many other causes $[95,107,168-170]$. Similarly, experimental renal fibrosis associated with high-fat diets [171], unilateral ureteral obstruction [172], high-dose folate intake [96], adenine [173], and cyclosporin A [174] was significantly reduced with metformin. Accumulated data have shown that metformin has great potential in reducing the progression of fibrosis in various organs, including the VAT [174,175], SAT [176], uterus and ovaries [177], lungs [88,170], and liver [178]. At the same time, metformin decreased not only the severity of fibrosis induced by hyperinsulinemia, oxidative stress, and hyperglycemia in metabolic syndrome and type $2 \mathrm{DM}$, but also fibrosis of a different genesis-ischemic, toxic, and drug induced.

Interestingly, metformin administration did not alter AMPK and p38 MAPK activity or collagen levels in TGF- $\beta 1$ or cardiac fibroblasts with high glucose content [179]. This may support the idea that the anti-fibrotic effects of metformin are also most pronounced at the stages of high-fat nutrition, hyperinsulinemia, and IR prior to the formation of severe hyperglycemia. At the same time, metformin can reduce the hyperglycemia-induced inhibition of the B1/AMPK/Akt pathway, activate GSK3- $\beta$, and prevent diabetes-induced cardiomyopathy [102], suggesting that, while some mechanisms of the protective effects of metformin are weakened under hyperglycemic conditions, others are characterized by high functionality.

Nearly all the mechanisms underlying the development of HFpEF and diabetic kidney injury are blocked by metformin. In general, they reflect the universal processes of diabetic damage under the conditions of hyperinsulinemia and hyperglycemia: changes in the signaling of the Akt-AMPK-mTOR axis, induction of ER stress and epithelial-to-mesenchymal 
transition (EMT), inhibition of autophagy processes, generation and accumulation of ROS and AGE; under the influence of chronic hypoxia, an increase in hypoxia-inducible factor (HIF) activity, lipotoxicity, including inhibition of CREBP1 and FAS occurs. ER stress under hyperglycemic conditions is caused by protein accumulation, ROS generation, and mTOR activation in both cardiomyocytes and renal epithelial cells. AMPK activation by metformin protects the myocardium, renal epithelial cells, and other tissues from ER stress by inhibiting the long-term UPR, ROS generation, and mTOR activation. In obesity and type 2 DM, ER stress, which develops under the influence of hypoxia and/or glucose deficiency in the cell, plays an essential role in the activation of the expression of glucose-regulated protein 78 (GRP78). Recently, data on the ability of metformin to influence its activity have been obtained [180].

Moreover, the modulation of GRP78 activity by metformin turned out to play a significant role in its antitumor activity [181] and in improving the prognosis in COVID-19. Modulation of GRP78 activity may contribute to the implementation of many metformin action mechanisms. Normally, GRP78 is localized in the ER, where it plays an important role in the folding and assembly of proteins and, conversely, in the "re-folding" of misfolded/unfolded proteins or their degradation [181].

Under pathological conditions, such as during hypoxia, glucose starvation, in cells infected with fungi and viruses, and in tumor cells, this protein is overexpressed on the cell membrane and can be detected in the circulation in a soluble form. Overexpression of GRP78 on the cell surface facilitates the entry of pathogens (bacterial, fungal, and viral) into the cells and increases the aggressiveness of cancers. The pronounced overexpression of GRP78 in adipose tissue and pancreatic cells in visceral obesity, which is a consequence of hypoxia and intracellular glucose deficiency as a result of IR, is most likely the primary target of metformin in realizing its effects on adipose tissue health, improving the prognosis in COVID-19, and improving the response to treatment of many tumors. In fact, improving cell viability under hypoxic conditions can be identified as the key effect of metformin. Hypoxia and an increase in the level of angiotensin II under its influence in diabetic nephropathy cause the elevation in intrarenal and systemic pressure and the accumulation of collagen. These processes are accompanied by hypoxia-induced rise in HIF1a. The ability of metformin to reduce the severity of these processes has been confirmed by the effect of metformin on the HIF1a level in diabetic nephropathy, which is realized through the inhibition of the mitochondrial respiratory complex I and the oxygen redistribution in the cells. Metformin reduces oxygen demand and consumption and lowers ATP levels, which in turn promotes proteasome degradation of HIF1a and prevents hypoxia-induced damage to renal epithelial cells. Metformin may also protect podocytes in diabetic nephropathy [182]. Metformin, blocking the AGEs-AGER-ROS axis, exhibits its antioxidant effect and reduces the risk of cellular damage, which has been found to contribute to non-diabetic kidney disease, thus reducing the risk of kidney stones formation. Metformin decreases the severity of inflammation, the penetration of immunocytes into the renal epithelium, and modulates their functions (including in acute renal injury), activates the autophagy process in renal diseases, and reduces apoptosis in an AMPK-dependent way, through mechanisms similar to those described above for HFpEF. Finally, metformin reduces lipotoxicity by inhibiting the cellular damage processes even at the stage of obesity, improving lipid metabolism and protecting cardiomyocytes and mesangial kidney cells from apoptosis caused by lipotoxicity. As already noted, metformin resolves or inhibits pathological processes in non-diabetic renal damage as well. In addition to the abovementioned effect on urolithiasis development, metformin inhibits the progression of autosomal dominant polycystic kidney disease, interfering with cell proliferation and inhibiting cystic fibrosis transmembrane conductance regulator (CFTR) and mTOR signals through AMPK. The ability of metformin to protect the kidney from the toxic effects of nephrotoxic drugs deserves special attention. It protects the renal tubules from damage by regulating oxidative stress and repairing biochemical changes. 
An important metformin effect on inhibiting the progression of virtually any renal pathology is its ability to protect against the development of renal fibrosis. Metformin slows down the renal hypoxia-induced fibrosis by inhibiting the stabilization of $\operatorname{HIF} 1 \alpha$, decreasing renal oxygen consumption, reducing the TGF- $\beta 1$ level, and blocking its binding to the receptor.

\section{Clinical Findings for the Cardioprotective Effects of Metformin on the Cardiorenal Continuum (HFpEF and CKD)}

Currently, the effects of metformin therapy have been evaluated in different HF phenotypes. If in HF with reduced ejection fraction metformin had a neutral effect on the risk of death and reduced the risk of hospitalizations, then in HFpEF, metformin therapy was associated with a decrease in the risk of death, as in acute HF. In the abovementioned meta-analysis by Halabi et al., a significantly greater protective effect was observed in patients with $\mathrm{EF}>50 \%(p=0.003)$.

In patients with diabetes mellitus, metformin improved both the Doppler measurement of the long-axis lengthening rate $(\mathrm{e} 0)$ and the isovolumic relaxation time, which indicates an improvement in the echocardiography changes that are characteristic of HFpEF [183].

The results of Facila et al. (2016) look impressive: according to this study the use of metformin in the treatment of patients with type $2 \mathrm{DM}$ and acute HF has beneficial effects, reducing the risk of death by $67 \%(p<0.001)$, regardless of age, gender, EF, GFR, and prescribed antidiabetic drugs [184]. However, despite growing evidence of the reduced death risk, the current guidelines require discontinuation of metformin therapy in patients with acute conditions associated with the risk of lactic acidosis, such as cardiogenic shock or acute HF [185].

\section{Metformin in Atherogenesis Inhibition}

\subsection{Experimental Findings Concerning Metformin Effects on Atherogenesis}

Currently, a large pool of data has accumulated demonstrating the important effects of metformin on (a) the elastic properties and biological age of the blood vessels, (b) the processes of lipid accumulation in the vascular wall, and (c) the activation processes of macrophages, formation of their various phenotypes, formation of foam cells, and in a clinical aspect, the formation and stability of atherosclerotic plaque. Virtually all signs of early vascular aging (genomic instability, epigenetic changes, telomere attrition, proteostasis, loss of proteostasis, mitochondrial dysfunction, deregulated nutrient sensing, cellular senescence, stem cell exhaustion, altered intercellular communication) can be modulated by metformin $[75,186]$. These data include the ability of metformin to slow the increase in arterial stiffness and pulse wave velocity and the formation of impaired endothelial function and vasodilation; to inhibit chronic vascular inflammation and intimamedia complex thickening; to prevent or to reduce the impairment of the blood rheological properties; to prevent the depletion of the capillary network and its dysfunction; to decrease telomere length and telomerase activity; to prevent impaired glucose and lipid metabolism and oxidative stress; to inhibit arterial calcification, an increase the matrix substances deposition, and disorganization of the small vessels in the kidneys and brain; and to level the increase in load on the LV, reducing its hypertrophy. It is important to note that, even at the IR stage, the ability of adipocytes to accumulate free fatty acids is impaired, and their level in circulation, especially in the postprandial status, increases, which leads to an increase in the de novo synthesis of DAG. This activates PKC, which in turn is responsible for the hyperproduction of endothelial $\mathrm{O}_{2}$ radicals and eNOS inhibition. Metformin prevents the adverse effects of excess dietary fat and carbohydrates, including the effects on vascular function [187]. At the DM stage, metformin can reduce hyperglycemia-induced endothelial senescence and apoptosis through a SIRT1-dependent pathway and inhibit OS both under hyperglycemic conditions (in rats and humans) and under fructose or palmitic acid-rich diets. Metformin increases endogenous antioxidant defenses by preventing 
hyperglycemia-related inhibition of glucose-6-phosphate dehydrogenase, which prevents a decrease in superoxide dismutase- 1 production and counteracts the proatherogenic effects of oxidized low-density lipoproteins (oxLDLs) and lectin-like oxLDL receptor LOX-1 [187].

Inhibition of the respiratory complex I in mitochondria by metformin is accompanied by a decrease in ATP production and a concomitant increase in adenosine diphosphate and AMP. This altered cellular energy charge is detected by the main cellular energy sensor, AMPK (Table 2) [116,117]. Experimental studies in ApoE -/- mice have demonstrated the ability of metformin to inhibit atherosclerotic plaque formation, compared to untreated animals (Table 2).

Metformin protects against atherosclerosis by maintaining endothelial integrity and preventing plaque formation by inhibiting lipid entry into the vascular wall. DM is wellknown to be characterized by severe plaque instability (Table 2) [142].

In addition, metformin exhibits antithrombotic properties, counteracting the stimulating effect of hyperinsulinemia on the production of an inhibitor of plasminogen activator inhibitor 1 (PAI-1), a negative regulator of fibrinolysis. Metformin directly inhibits the expression of the PAI-1 gene (Table 2). Studies that examined the effect of metformin on the course of acute myocardial ischemia have yielded fewer striking results. In our center, a clinical and experimental study on the effect of metformin on myocardial resistance to ischemia both in diabetes and in its absence was carried out. The effect of metformin on myocardial resistance to ischemic and reperfusion injury was shown only after its intracoronary administration in animals without DM. These results were explained by the highest concentration of the drug achieved in the myocardium. In addition, given that diabetes itself affected ischemic preconditioning of the myocardium, it is possible that the activation of the defense mechanisms in the myocardium associated with the presence of diabetes cannot be enhanced by an additional stimulus [188]. In experimental studies, treatment with metformin was accompanied by the improvement in the functional state of the heart and the inhibition of the HF progression of ischemic and non-ischemic etiology, improving the energy status of the myocardium [189].

\subsection{Clinical Evidence of the Cardioprotective Effects of Metformin on Atherosclerotic CVD}

According to a recent review [187], metformin reduces the risk of the development and the progression of atherosclerosis by reducing the severity of IR and inflammation, most importantly, and a number of CV risk factors (dyslipidemia, hypertension, glycemia, obesity) and by counteracting the proatherogenic role of oxLDL and LOX-1. These effects have been confirmed in studies on patients with and without type 2 DM. We fully support the opinion of the authors that the main atheroprotection effect of metformin is provided by an improvement in insulin sensitivity and, as a result, a decrease in the severity of inflammation and OS.

One of the earliest and longest-running studies demonstrating the positive effects of metformin on the CVD prognosis was the UKPDS study, which demonstrated the ability of metformin to reduce the risk of atherosclerotic cardiovascular events (MI), overall mortality, and diabetes-associated death after the end of the study (UKPDS34) and after 10 years of follow-up (UKPDS80).

The efficacy of metformin in the primary prevention of $\mathrm{CV}$ events has been confirmed in a retrospective study [190] that compared 3400 patients with type 2 DM who received metformin and lifestyle modification with patients $(n=3400)$ treated only with lifestyle modification (control group). All patients had no CVD. The average follow-up period was 62.5 months (about 5 years). In the metformin group, there was a decrease in the risk of mortality from all causes by $29.5 \%(p=0.007)$, coronary heart disease by $35.5 \%(p=0.004)$, chronic HF by $31.2 \%(p=0.109)$, and stroke by $30.2 \%(p=0.024)$ in comparison with the control group.

Regarding the ability of metformin to provide a secondary prevention of atherothrombotic events, the Reduction of Atherothrombosis for Continued Health (REACH) Registry provided a strong evidence base in the analysis of almost 20,000 patients. A decrease 
in overall mortality was demonstrated when taking metformin for 2 years (hazard ratio $0.67 ; 95 \%$ confidence interval (CI) $0.59-0.75$; adjusted hazard ratio 0.76 ; $95 \%$ confidence interval $0.65-0.89$ ( $p$-value 0.001 for both, log-rank test)). Hazard ratios were adjusted for age, gender, and significant risk factors [191,192].

Mortality was 6.3\% (95\% CI 5.2-7.4\%) with metformin and 9.8\% (95\% CI 8.4-11.2\%) without metformin (relative risk $0.76(95 \%$ CI $0.65-0.89 ; p<0.001)$ ). Association with lower mortality was consistent among the subgroups, including those with a history of congestive HF (relative risk $0.69 ; 95 \%$ CI $0.54-0.90 ; p=0.006)$, elderly patients ( $>65$ years old $(0.77$; $0.62-0.95 ; p=0.02)$, and patients with GFR 30-60 mL/min $/ 1.73 \mathrm{~m}^{2}$ (0.64; 95\% CI, 0.48-0.86; $p=0.003$ ). Metformin use has been shown to reduce mortality among diabetic patients as a secondary prophylaxis, including those subgroups of patients in which the use of metformin had not been recommended.

Until recently, metformin was not recommended for patients with acute MI [193]; however, publications in recent years have indicated the need to change the current paradigm. They have evidenced a reduced risk of death in patients with MI when receiving metformin, while insulin therapy, on the contrary, worsened the prognosis [194]. Another analysis compared the effect of metformin with sulfonylurea drugs and thiazolidinediones on the outcome of the first MI. Type 2 DM patients receiving metformin during the acute phase of the first MI showed a significantly lower incidence of CV complications $(p=0.005)$ compared with those who did not receive it, including the risk of recurrent MI based on multivariate analysis (hazard ratio $0.33 ; 95 \%$ CI $0.12-0.91 ; p=0.032$ ). The effect persisted after the adjustment for other risk factors [195].

As noted above, HFrEF is predominantly an outcome of atherosclerotic CVD, especially with acute events (MI), so the effects of metformin on its course should be considered in this section. In the study by Eurich et al., in individuals with chronic HF and low left ventricular ejection fraction, metformin did not increase or decrease the risk of death (relative risk 0.91,95\% CI 0.72-1.14; $p=0.34$ ) [196]. At the same time, the use of metformin was associated with a significant reduction in the risk of all hospitalizations by $7 \%$ (95\% CI $0.89-0.98 ; p=0.01)$ without a rise in the risk of lactic acidosis. For many years, metformin has not been recommended for HF because of the risk of increased lactate levels and the development of lactic acidosis. However, the results of clinical observations have shown that this risk is ephemeral, and in reality, metformin therapy improves the survival rate of patients with HF. The mechanism of this effect includes the activation of AMP, which ensures the regression of cardiomyocyte hypertrophy, the suppression of cell apoptosis, the prevention of myocardial fibrosis, and the stimulation of NO synthesis. We will discuss the role of lactate in these processes below. In the later meta-analysis, metformin reduced mortality in HF with both preserved and reduced EF after adjusting for HF treatments such as ACE inhibitors and beta-blockers $(\beta=-0.2$ (95\% CI -0.3 to -0.1$), p=0.02)$ [197].

\section{Role of Lactate Elevation in Realization of Metformin Effects}

Meanwhile, studies in recent years have changed our view concerning the role of lactate in the organism. An increase in lactate production occurs with a reduction in aerobic glycolysis under hypoxic conditions, which is accompanied by a compensatory increase in the activity of anaerobic glycolysis and the level of lactate in the circulation. In this variant, lactate acts as a marker of metabolic health [198]. Lactate level in the blood in obese patients is significantly higher than in people with normal body weight, reflecting an increase in tissue hypoxia, in particular, hypoxia of adipose tissue, as adipocyte hypertrophy develops. These changes predict the development of oxidative stress and chronic inflammation, which characterize the deterioration of metabolic health. The opposite results were also noted: after bariatric treatment with normalization of the body weight, there was also a decrease in lactate level in the circulation [198]. Moderately elevated lactate levels are often observed in patients with an advanced functional class of HF and in other critical conditions (patients with severe renal failure, brain injury). This, to a certain extent, reflects the characteristics of energy metabolism in hypoxic conditions. New data regarding the role of increased 
muscle lactate in exercise tolerance have also been obtained. A moderate increase in lactate seems to improve the muscle tolerance to stress, and at high concentrations it worsens. With physical exertion, the need for ATP in the muscles increases with insufficient oxygen supply, and the production of lactate grows. Lactate is involved in muscle fiber interactions (lactate intercellular shuttle) during physical activity. Lactate is actively used by the myocardial fibers and the brain. Thus, in recent years, the place of lactate in energy metabolism has dramatically changed, especially in neural energy metabolism [199]. There is accumulated evidence that lactate may act as a "critical rescue fuel" for the CNS when glucose concentrations fluctuate over a wide range. In the CNS, the lactic acid shuttle of astrocyte neurons provides a mechanism through which astrocytes provide energy metabolism, converting glucose to lactate via glycolysis. This astrocytic lactate spreads from astrocytes to the adjacent neurons, where it is oxidized in the mitochondria (to $\mathrm{CO}_{2}+\mathrm{H}_{2} \mathrm{O}$ ) to resynthesize ATP and/or be used to produce amino acid neurotransmitters (e.g., glutamate, aspartate, and $\gamma$-aminobutyric acid (GABA)). An increased level of lactate in the CNS plays an important role in tumors. Lactate is the "rescue fuel" for the normal CNS cells in cancer, since tumor cells actively exporting lactate have a very low ability to import and use lactate for metabolism. At the same time, tumor cells are more active glucose consumers, which can lead to "consumption hypoglycemia." Thus, tumor cells actively consume glucose, but they are unable to utilize lactate [200]. Hyperlactatemia is a compensatory mechanism that provides energy to normal cells in cancer, including in conditions of hypoglycemia, and this may be one of the mechanisms for improving the prognosis in cancer patients given metformin.

Today lactate is discussed as an extremely useful energy substrate and anti-inflammatory agent, since in inflammatory processes it can inhibit inflammasomes in traumatic brain injury; in acute damage of the pancreas and the liver; in MI, heart surgery and acute HF; and in several other urgent situations [201]. At the same time, the regulation of redox/ROS, calcium/calmodulin-activated protein kinase II (CaMK II)/PKC and PGC1a has been discussed as the key mechanisms of its action, which indicates the role of lactate in the realization of metformin's effects. Therefore, the view of metformin therapy as an option that must be interrupted in urgent situations because of the risk of lactic acidosis may be outdated. The review discussing the risk of lactic acidosis from metformin therapy claimed that metformin-induced lactic acidosis arises only in cases where three conditions are met: lactate level $>5 \mathrm{mmol} / \mathrm{L}, \mathrm{pH}<7.35$, and metformin concentration in the circulation $>5 \mathrm{mg} / \mathrm{L}$. Only $10 \%$ of cases of lactic acidosis described as metformin-associated met these criteria [202]. In most cases that are recorded as metformin-induced LA, the latter only limited the ability of patients to cope with an increase in lactate levels caused by another event (not metformin) that triggered LA. Moreover, LA patients treated with metformin have a significantly better prognosis than LA patients not receiving metformin [203]. Thus, the risk of lactic acidosis developing from metformin is seriously exaggerated, and in most cases, this therapy gives only moderate hyperlactatemia, which does not worsen the prognosis in urgent situations, but, on the contrary, can improve the energy metabolism and survival. In addition, the latest theories of diabetes development have put redox stress on the list of the earliest changes, appearing long before the development of carbohydrate metabolism disorders inducing a cascade of subsequent pathological events. This once again leads us to the usefulness of the earliest administration of metformin in situations with a high risk of prediabetes and diabetes development.

It is possible to draw an analogy to the effects of SGLT2 inhibitors. The increase in the production of ketones allows these drugs to provide a convenient and economical treatment in terms of an oxygen consumption variant of the energy substrate, which is much more suitable for organs in the state of hypoxia. Energy metabolism changes from lipolysis to ketolysis in damaged kidneys [204] and heart [205]. Hyperactivation of mTORC1 leads to a decrease in renal lipolysis with subsequent renal damage. Elevated ketone bodies increase the severity of renal damage by blocking mTORC1 signals. Thus, the mechanisms of reno- and cardioprotection of SGLT2 inhibitors include the inhibition of mTORC1 by 
ketone bodies [204], and this largely resembles the effects of metformin, also including the inhibition of mTOR and providing an energy substrate suitable for use under hypoxic conditions (lactate).

\section{Conclusions}

Summing up, we note that the accumulated data indicate the possibility of expanding the boundaries of metformin use toward more new targets: anti-aging therapy [186], improvement in the treatment of many types of cancer [205], renal pathology of both diabetic and non-diabetic (toxic and ischemic) genesis, many profibrogenic diseases, and in the direction of expanding the possibilities of its use in diabetes mellitus and in risk groups for its development. At the same time, we are moving toward prescribing it increasingly earlier in treatment, and it can be assumed that new large studies will prove that the moment to start metformin should occur earlier than prediabetes in situations with a high risk of developing metabolic disease. These include an unhealthy lifestyle with intake of high animal fat and high glycemic index food, low physical activity, increasing excess weight with a tendency to visceral fat deposition. Recent studies have shown that already at this stage an imbalance in microbiota phenotypes has developed with a decrease in the number and diversity of butyrate-producing and lactate-producing bacteria, impaired production of incretins, and the formation of redox stress and oxidative stress. This will lead to a future deterioration in secretion and a decrease in the number of $\beta$-cells, development of hyperglucagonemia, and progression of metabolic and vascular changes whose reversibility is debatable. Intervention with metformin as early as possible protects one, to a certain extent, from the negative influences of an unhealthy lifestyle, giving the patient a temporary head start to change it. On the other hand, we have received more and more data about conditions that were previously considered as contradictions to metformin use where metformin therapy improved the prognosis compared to most antidiabetic drugs. In these cases, we consider the ability of metformin to increase resistance to hypoxia and cell survival under hypoxic and toxic conditions as a key mechanism. Moderate hyperlactatemia accompanying metformin therapy may play a significant role in these adaptive mechanisms. Further studies are needed to finally resolve the question of lifting restrictions on the use of metformin in acute heart failure, in the acute period of MI, and in a number of other acute conditions, including infectious diseases (COVID-19), considering the recent data showing a significant improvement in their prognosis with metformin therapy.

Funding: The APC was funded by the Ministry of Science and Higher Education of the Russian Federation (Agreement No. 075-15-2020-901).

Institutional Review Board Statement: Not applicable.

Informed Consent Statement: Not applicable.

Conflicts of Interest: The authors declare no conflict of interest.

\section{References}

1. Jenkins, D.J.; Dehghan, M.; Mente, A.; Bangdiwala, S.I.; Rangarajan, S.; Srichaikul, K.; Mohan, V.; Avezum, A.; Díaz, R.; Rosengren, A.; et al. Glycemic Index, Glycemic Load, and Cardiovascular Disease and Mortality. N. Engl. J. Med. 2021, 384, 1312-1322. [CrossRef] [PubMed]

2. Leow, M.K.; Henry, C.J. Glycemic Index, Glycemic Load, and Cardiovascular Disease and Mortality. N. Engl. J. Med. 2021, 385, 378-380. [CrossRef] [PubMed]

3. Kirkpatrick, C.F.; Maki, K.C. Dietary Influences on Atherosclerotic Cardiovascular Disease Risk. Curr. Atheroscler. Rep. 2021, 23, 1-9. [CrossRef] [PubMed]

4. Morigny, P.; Boucher, J.; Arner, P.; Langin, D. Lipid and glucose metabolism in white adipocytes: Pathways, dysfunction and therapeutics. Nat. Rev. Endocrinol. 2021, 17, 276-295. [CrossRef]

5. Stenkula, K.G.; Erlanson-Albertsson, C. Adipose cell size: Importance in health and disease. Am. J. Physiol. Regul. Integr. Comp. Physiol. 2018, 315, R284-R295. [CrossRef] 
6. Vishvanath, L.; Gupta, R.K. Contribution of adipogenesis to healthy adipose tissue expansion in obesity. J. Clin. Investig. 2019, 129, 4022-4031. [CrossRef]

7. Million, M.; Angelakis, E.; Paul, M.; Armougom, F.; Leibovici, L.; Raoult, D. Comparative meta-analysis of the effect of Lactobacillus species on weight gain in humans and animals. Microb. Pathog. 2012, 53, 100-108. [CrossRef]

8. Borgeraas, H.; Johnson, L.K.; Skattebu, J.; Hertel, J.K.; Hjelmesaeth, J. Effects of probiotics on body weight, body mass index, fat mass and fat percentage in subjects with overweight or obesity: A systematic review and meta-analysis of randomized controlled trials. Obes. Rev. 2018, 19, 219-232. [CrossRef]

9. Eckburg, P.B.; Bik, E.M.; Bernstein, C.N.; Purdom, E.; Dethlefsen, L.; Sargent, M.; Gill, S.R.; Nelson, K.E.; Relman, D.A. Diversity of the Human Intestinal Microbial Flora. Science 2005, 308, 1635-1638. [CrossRef]

10. van Son, J.; Koekkoek, L.; La Fleur, S.; Serlie, M.; Nieuwdorp, M. The Role of the Gut Microbiota in the Gut-Brain Axis in Obesity: Mechanisms and Future Implications. Int. J. Mol. Sci. 2021, 22, 2993. [CrossRef]

11. Hur, K.Y.; Lee, M. New mechanisms of metformin action: Focusing on mitochondria and the gut. J. Diabetes Investig. 2015, 6 , 600-609. [CrossRef] [PubMed]

12. Turnbaugh, P.J.; Hamady, M.; Yatsunenko, T.; Cantarel, B.L.; Duncan, A.; Ley, R.E.; Sogin, M.L.; Jones, W.J.; Roe, B.A.; Affourtit, J.P.; et al. A core gut microbiome in obese and lean twins. Nature 2009, 457, 480-484. [CrossRef] [PubMed]

13. Larsen, N.; Vogensen, F.K.; Van Den Berg, F.W.J.; Nielsen, D.S.; Andreasen, A.S.; Pedersen, B.K.; Al-Soud, W.A.; Sørensen, S.J.; Hansen, L.H.; Jakobsen, M. Gut Microbiota in Human Adults with Type 2 Diabetes Differs from Non-Diabetic Adults. PLoS ONE 2010, 5, e9085. [CrossRef]

14. Zhang, F.; Wang, M.; Yang, J.; Xu, Q.; Liang, C.; Chen, B.; Zhang, J.; Yang, Y.; Wang, H.; Shang, Y.; et al. Response of gut microbiota in type 2 diabetes to hypoglycemic agents. Endocrine 2019, 66, 485-493. [CrossRef] [PubMed]

15. Ahmad, A.; Yang, W.; Chen, G.; Shafiq, M.; Javed, S.; Zaidi, S.S.A.; Shahid, R.; Liu, C.; Bokhari, H. Analysis of gut microbiota of obese individuals with type 2 diabetes and healthy individuals. PLoS ONE 2019, 14, e226372. [CrossRef]

16. Chávez-Carbajal, A.; Pizano-Zárate, M.L.; Hernández-Quiroz, F.; Ortiz-Luna, G.F.; Morales-Hernández, R.M.; De Sales-Millán, A.; Hernández-Trejo, M.; García-Vite, A.; Beltrán-Lagunes, L.; Hoyo-Vadillo, C.; et al. Characterization of the Gut Microbiota of Individuals at Different T2D Stages Reveals a Complex Relationship with the Host. Microorganisms 2020, 8, 94. [CrossRef] [PubMed]

17. Zhang, X.; Shen, D.; Fang, Z.; Jie, Z.; Qiu, X.; Zhang, C.; Chen, Y.; Ji, L. Human Gut Microbiota Changes Reveal the Progression of Glucose Intolerance. PLoS ONE 2013, 8, e71108. [CrossRef] [PubMed]

18. Sato, J.; Kanazawa, A.; Ikeda, F.; Yoshihara, T.; Goto, H.; Abe, H.; Komiya, K.; Kawaguchi, M.; Shimizu, T.; Ogihara, T.; et al. Gut Dysbiosis and Detection of “Live Gut Bacteria” in Blood of Japanese Patients With Type 2 Diabetes. Diabetes Care 2014, 37, 2343-2350. [CrossRef]

19. Ollmann, M.M.; Wilson, B.D.; Yang, Y.K.; Kerns, J.A.; Chen, Y.; Gantz, I.; Barsh, G.S. Antagonism of Central Melanocortin Receptors in Vitro and in Vivo by Agouti-Related Protein. Science 1997, 278, 135-138. [CrossRef]

20. Cummings, D.E.; Purnell, J.Q.; Frayo, R.S.; Schmidova, K.; Wisse, B.E.; Weigle, D.S. A Preprandial Rise in Plasma Ghrelin Levels Suggests a Role in Meal Initiation in Humans. Diabetes 2001, 50, 1714-1719. [CrossRef]

21. Williams, D.L.; Cummings, D.E.; Grill, H.J.; Kaplan, J.M. Meal-Related Ghrelin Suppression Requires Postgastric Feedback. Endocrinology 2003, 144, 2765-2767. [CrossRef] [PubMed]

22. Müller, T.D.; Nogueiras, R.; Andermann, M.L.; Andrews, Z.B.; Anker, S.; Argente, J.; Batterham, R.; Benoit, S.; Bowers, C.; Broglio, F.; et al. Ghrelin. Mol. Metab. 2015, 4, 437-460. [CrossRef] [PubMed]

23. Yanagi, H.; Tsuda, A.; Matsushima, M.; Takahashi, S.; Ozawa, G.; Koga, Y.; Takagi, A. Changes in the gut microbiota composition and the plasma ghrelin level in patients withHelicobacter pylori-infected patients with eradication therapy. BMJ Open Gastroenterol. 2017, 4, e000182. [CrossRef] [PubMed]

24. Xiong, Y.; Miyamoto, N.; Shibata, K.; Valasek, M.A.; Motoike, T.; Kedzierski, R.M.; Yanagisawa, M. Short-chain fatty acids stimulate leptin production in adipocytes through the G protein-coupled receptor GPR41. Proc. Natl. Acad. Sci. USA 2004, 101, 1045-1050. [CrossRef]

25. Schéle, E.; Grahnemo, L.; Anesten, F.; Hallén, A.; Bäckhed, F.; Jansson, J.-O. Regulation of body fat mass by the gut microbiota: Possible mediation by the brain. Peptides 2016, 77, 54-59. [CrossRef]

26. Flier, J.S.; Maratos-Flier, E. Leptin's Physiologic Role: Does the Emperor of Energy Balance Have No Clothes? Cell Metab. 2017, 26, 24-26. [CrossRef]

27. Fung, C.; Van den Berghe, P. Functional circuits and signal processing in the enteric nervous system. Cell. Mol. Life Sci. 2020, 77, 4505-4522. [CrossRef]

28. Li, Y.; Owyang, C. Musings on the Wanderer: What's New in Our Understanding of Vago-Vagal Reflexes? V. Remodeling of vagus and enteric neural circuitry after vagal injury. Am. J. Physiol. Liver Physiol. 2003, 285, G461-G469. [CrossRef]

29. Kabouridis, P.S.; Lasrado, R.; McCallum, S.; Chng, S.H.; Snippert, H.J.; Clevers, H.; Pettersson, S.; Pachnis, V. Microbiota Controls the Homeostasis of Glial Cells in the Gut Lamina Propria. Neuron 2015, 85, 289-295. [CrossRef]

30. Chambers, E.S.; Viardot, A.; Psichas, A.; Morrison, D.J.; Murphy, K.G.; Zac-Varghese, S.E.K.; MacDougall, K.; Preston, T.; Tedford, M.C.; Finlayson, G.; et al. Targeted delivery of propionate to the colon stimulates the release of anorectic gut hormones and suppresses appetite in humans. Proc. Nutr. Soc. 2014, 73, OCE1. [CrossRef] 
31. Lynn, F.C.; Thompson, S.A.; Pospisilik, J.A.; Ehses, J.; Hinke, S.A.; Pamir, N.; McIntosh, C.H.S.; Pederson, R.A. A novel pathway for regulation of glucose-dependent insulinotropic polypeptide receptor expression in $\beta$-cells. FASEB J. 2002, 17, 91-93. [CrossRef]

32. Smith, G.P.; Jerome, C.; Cushin, B.J.; Eterno, R.; Simansky, K.J. Abdominal Vagotomy Blocks the Satiety Effect of Cholecystokinin in the Rat. Science 1981, 213, 1036-1037. [CrossRef]

33. Bauer, P.V.; Hamr, S.C.; Duca, F.A. Regulation of energy balance by a gut-brain axis and involvement of the gut microbiota. Cell. Mol. Life Sci. 2015, 73, 737-755. [CrossRef] [PubMed]

34. Rehfeld, J.F.; Friis-Hansen, L.; Goetze, J.P.; Hansen, T.V.O. The biology of cholecystokinin and gastrin peptides. Curr. Top. Med. Chem. 2007, 7, 1154-1165. [CrossRef] [PubMed]

35. Gibbs, J.P.; Young, R.C.; Smith, G.P. Cholecystokinin elicits Satiety in Rats with Open Gastric Fistulas. Nature 1973, $245,323-325$. [CrossRef] [PubMed]

36. Egecioglu, E.; Jerlhag, E.; Salomé, N.; Skibicka, K.P.; Haage, D.; Bohlooly, Y.M.; Andersson, D.; Bjursell, M.; Perrissoud, D.; Engel, J.A.; et al. Ghrelin increases intake of rewarding food in rodents. Addict. Biol. 2010, 15, 304-311. [CrossRef] [PubMed]

37. Bohula, E.A.; Wiviott, S.D.; McGuire, D.K.; Inzucchi, S.E.; Kuder, J.; Im, K.; Fanola, C.L.; Qamar, A.; Brown, C.; Budaj, A.; et al. Cardiovascular Safety of Lorcaserin in Overweight or Obese Patients. N. Engl. J. Med. 2018, 379, 1107-1117. [CrossRef]

38. Mahase, E. Weight loss pill praised as "holy grail" is withdrawn from US market over cancer link. BMJ 2020, 368, m705. [CrossRef]

39. Young, R.L.; Lumsden, A.L.; Martin, A.M.; Schober, G.; Pezos, N.; Thazhath, S.S.; Isaacs, N.J.; Cvijanovic, N.; Sun, E.W.-L.; Wu, T.; et al. Augmented capacity for peripheral serotonin release in human obesity. Int. J. Obes. 2018, 42, 1880-1889. [CrossRef]

40. Palacios, T.; Vitetta, L.; Coulson, S.; Madigan, C.D.; Lam, Y.Y.; Manuel, R.; Briskey, D.; Hendy, C.; Kim, J.-N.; Ishoey, T.; et al. Targeting the Intestinal Microbiota to Prevent Type 2 Diabetes and Enhance the Effect of Metformin on Glycaemia: A Randomised Controlled Pilot Study. Nutrients 2020, 12, 2041. [CrossRef]

41. de la Cuesta-Zuluaga, J.; Mueller, N.T.; Corrales-Agudelo, V.; Velásquez-Mejía, E.P.; Carmona, J.A.; Abad, J.M.; Escobar, J.S. Metformin Is Associated With Higher Relative Abundance of Mucin-Degrading Akkermansia muciniphilaand Several ShortChain Fatty Acid-Producing Microbiota in the Gut. Diabetes Care 2017, 40, 54-62. [CrossRef] [PubMed]

42. Kim, J.; Kwak, H.J.; Cha, J.-Y.; Jeong, Y.-S.; Rhee, S.D.; Kim, K.R.; Cheon, H.G. Metformin Suppresses Lipopolysaccharide (LPS)-induced Inflammatory Response in Murine Macrophages via Activating Transcription Factor-3 (ATF-3) Induction. J. Biol. Chem. 2014, 289, 23246-23255. [CrossRef] [PubMed]

43. Sun, J.; Huang, N.; Ma, W.; Zhou, H.; Lai, K. Protective effects of metformin on lipopolysaccharide-induced airway epithelial cell injury via NF-кB signaling inhibition. Mol. Med. Rep. 2019, 19, 1817-1823. [CrossRef] [PubMed]

44. Harte, A.L.; Varma, M.C.; Tripathi, G.; McGee, K.C.; Al-Daghri, N.M.; Al-Attas, O.S.; Sabico, S.; O'Hare, J.P.; Ceriello, A.; Saravanan, P.; et al. High Fat Intake Leads to Acute Postprandial Exposure to Circulating Endotoxin in Type 2 Diabetic Subjects. Diabetes Care 2012, 35, 375-382. [CrossRef]

45. Reilly, S.M.; Saltiel, A.R. Adapting to obesity with adipose tissue inflammation. Nat. Rev. Endocrinol. 2017, 13, 633-643. [CrossRef]

46. Hersoug, L.; Møller, P.; Loft, S. Gut microbiota-derived lipopolysaccharide uptake and trafficking to adipose tissue: Implications for inflammation and obesity. Obes. Rev. 2016, 17, 297-312. [CrossRef]

47. De La Serre, C.B.; Ellis, C.L.; Lee, J.; Hartman, A.L.; Rutledge, J.C.; Raybould, H.E. Propensity to high-fat diet-induced obesity in rats is associated with changes in the gut microbiota and gut inflammation. Am. J. Physiol. Liver Physiol. 2010, 299, G440-G448. [CrossRef]

48. Cani, P.D.; Amar, J.; Iglesias, M.A.; Poggi, M.; Knauf, C.; Bastelica, D.; Neyrinck, A.M.; Fava, F.; Tuohy, K.M.; Chabo, C.W.; et al. Metabolic endotoxemia initiates obesity and insulin resistance. Diabetes 2007, 56, 1761-1772. [CrossRef]

49. Gribble, F.M.; Reimann, F. Enteroendocrine Cells: Chemosensors in the Intestinal Epithelium. Annu. Rev. Physiol. 2016, 78, 277-299. [CrossRef]

50. Worthington, J.J.; Reimann, F.; Gribble, F. Enteroendocrine cells-sensory sentinels of the intestinal environment and orchestrators of mucosal immunity. Mucosal Immunol. 2017, 11, 3-20. [CrossRef]

51. Symonds, E.L.; Peiris, M.; Page, A.J.; Chia, B.; Dogra, H.; Masding, A.; Galanakis, V.; Atiba, M.; Bulmer, D.; Young, R.L.; et al Mechanisms of activation of mouse and human enteroendocrine cells by nutrients. Gut 2015, 64, 618-626. [CrossRef] [PubMed]

52. Koda, S.; Date, Y.; Murakami, N.; Shimbara, T.; Hanada, T.; Toshinai, K.; Niijima, A.; Furuya, M.; Inomata, N.; Osuye, K.; et al. The Role of the Vagal Nerve in Peripheral PYY3-36-Induced Feeding Reduction in Rats. Endocrinology 2005, 146, $2369-2375$. [CrossRef] [PubMed]

53. Soraya, H.; Clanachan, A.S.; Rameshrad, M.; Maleki-Dizaji, N.; Ghazi-Khansari, M.; Garjani, A. Chronic treatment with metformin suppresses toll-like receptor 4 signaling and attenuates left ventricular dysfunction following myocardial infarction. Eur. J. Pharmacol. 2014, 737, 77-84. [CrossRef] [PubMed]

54. Di Fusco, D.; Dinallo, V.; Monteleone, I.; Laudisi, F.; Marafini, I.; Franzè, E.; Di Grazia, A.; Dwairi, R.; Colantoni, A.; Ortenzi, A.; et al. Metformin inhibits inflammatory signals in the gut by controlling AMPK and p38 MAP kinase activation. Clin. Sci. 2018, 132, 1155-1168. [CrossRef]

55. Hirsch, A.; Hahn, D.; Kempná, P.; Hofer, G.; Nuoffer, J.-M.; Mullis, P.E.; Flück, C.E. Metformin Inhibits Human Androgen Production by Regulating Steroidogenic Enzymes HSD3B2 and CYP17A1 and Complex I Activity of the Respiratory Chain. Endocrinology 2012, 153, 4354-4366. [CrossRef] 
56. Kurzthaler, D.; Hadziomerovic-Pekic, D.; Wildt, L.; Seeber, B.E. Metformin induces a prompt decrease in LH-stimulated testosterone response in women with PCOS independent of its insulin-sensitizing effects. Reprod. Biol. Endocrinol. 2014, 12, 1-6. [CrossRef]

57. Azhary, J.M.K.; Harada, M.; Takahashi, N.; Nose, E.; Kunitomi, C.; Koike, H.; Hirata, T.; Hirota, Y.; Koga, K.; Wada-Hiraike, O.; et al. Endoplasmic Reticulum Stress Activated by Androgen Enhances Apoptosis of Granulosa Cells via Induction of Death Receptor 5 in PCOS. Endocrinology 2019, 160, 119-132. [CrossRef]

58. Jin, J.; Ma, Y.; Tong, X.; Yang, W.; Dai, Y.; Pan, Y.; Ren, P.; Liu, L.; Fan, H.-Y.; Zhang, Y.; et al. Metformin inhibits testosteroneinduced endoplasmic reticulum stress in ovarian granulosa cells via inactivation of p38 MAPK. Hum. Reprod. 2020, 35, 1145-1158. [CrossRef]

59. Belkaid, Y.; Harrison, O. Homeostatic Immunity and the Microbiota. Immunity 2017, 46, 562-576. [CrossRef]

60. Postler, T.S.; Ghosh, S. Understanding the Holobiont: How Microbial Metabolites Affect Human Health and Shape the Immune System. Cell Metab. 2017, 26, 110-130. [CrossRef]

61. Nøhr, M.K.; Pedersen, M.H.; Gille, A.; Egerod, K.L.; Engelstoft, M.S.; Husted, A.S.; Sichlau, R.M.; Grunddal, K.V.; Poulsen, S.S.; Han, S.; et al. GPR41/FFAR3 and GPR43/FFAR2 as Cosensors for Short-Chain Fatty Acids in Enteroendocrine Cells vs FFAR3 in Enteric Neurons and FFAR2 in Enteric Leukocytes. Endocrinology 2013, 154, 3552-3564. [CrossRef] [PubMed]

62. Modasia, A.; Parker, A.; Jones, E.; Stentz, R.; Brion, A.; Goldson, A.; Defernez, M.; Wileman, T.; Blackshaw, L.A.; Carding, S.R Regulation of Enteroendocrine Cell Networks by the Major Human Gut Symbiont Bacteroides thetaiotaomicron. Front. Microbiol. 2020, 11, 5595. [CrossRef] [PubMed]

63. Bonaz, B.; Sinniger, V.; Pellissier, S. Anti-inflammatory properties of the vagus nerve: Potential therapeutic implications of vagus nerve stimulation. J. Physiol. 2016, 594, 5781-5790. [CrossRef] [PubMed]

64. Raybould, H.E. Gut chemosensing: Interactions between gut endocrine cells and visceral afferents. Auton. Neurosci. 2010, 153, 41-46. [CrossRef]

65. Gao, Z.; Yin, J.; Zhang, J.; Ward, R.E.; Martin, R.J.; Lefevre, M.; Cefalu, W.T.; Ye, J. Butyrate Improves Insulin Sensitivity and Increases Energy Expenditure in Mice. Diabetes 2009, 58, 1509-1517. [CrossRef]

66. Huuskonen, J.; Suuronen, T.; Nuutinen, T.; Kyrylenko, S.; Salminen, A. Regulation of microglial inflammatory response by sodium butyrate and short-chain fatty acids. J. Cereb. Blood Flow Metab. 2004, 141, 874-880. [CrossRef]

67. Møller, C.L.; Vistisen, D.; Færch, K.; Johansen, N.B.; Witte, D.; Jonsson, A.; Pedersen, O.; Hansen, T.; Lauritzen, T.; Jørgensen, M.E.; et al. Glucose-Dependent Insulinotropic Polypeptide Is Associated With Lower Low-Density Lipoprotein But Unhealthy Fat Distribution, Independent of Insulin: The ADDITION-PRO Study. J. Clin. Endocrinol. Metab. 2016, 101, 485-493. [CrossRef]

68. Hudish, L.I.; Reusch, J.E.; Sussel, L. $\beta$ Cell dysfunction during progression of metabolic syndrome to type 2 diabetes. J. Clin. Investig. 2019, 129, 4001-4008. [CrossRef]

69. Butler, A.E.; Jang, J.; Gurlo, T.; Carty, M.D.; Soeller, W.C.; Butler, P.C. Diabetes Due to a Progressive Defect in $\beta$-Cell Mass in Rats Transgenic for Human Islet Amyloid Polypeptide (HIP Rat). Diabetes 2004, 53, 1509-1516. [CrossRef]

70. Stepensky, D.; Friedman, M.; Raz, I.; Hoffman, A. Pharmacokinetic-Pharmacodynamic Analysis of the Glucose-Lowering Effect of Metformin in Diabetic Rats Reveals First-Pass Pharmacodynamic Effect. Drug Metab. Dispos. 2002, 30, 861-868. [CrossRef]

71. Bailey, C.; Mynett, K.; Page, T. Importance of the intestine as a site of metformin-stimulated glucose utilization. J. Cereb. Blood Flow Metab. 1994, 112, 671-675. [CrossRef] [PubMed]

72. Bailey, C.J.; Wilcock, C.; Scarpello, J.H.B. Metformin and the intestine. Diabetologia 2008, 51, 1552-1553. [CrossRef] [PubMed]

73. Lee, C.; Chae, S.; Jo, S.; Jerng, U.; Bae, S. The Relationship between the Gut Microbiome and Metformin as a Key for Treating Type 2 Diabetes Mellitus. Int. J. Mol. Sci. 2021, 22, 3566. [CrossRef] [PubMed]

74. Li, T.; Chiang, J.Y.L. Bile Acid Signaling in Metabolic Disease and Drug Therapy. Pharmacol. Rev. 2014, 66, 948-983. [CrossRef]

75. Sansome, D.J.; Xie, C.; Veedfald, S.; Horowitz, M.; Rayner, C.K.; Wu, T. Mechanism of glucose-lowering by metformin in type 2 diabetes: Role of bile acids. Diabetes Obes. Metab. 2020, 22, 141-148. [CrossRef]

76. Forslund, K.; Hildebrand, F.; Nielsen, T.; Falony, G.; Le Chatelier, E.; Sunagawa, S.; Prifti, E.; Vieira-Silva, S.; Gudmundsdottir V.; Krogh Pedersen, H.; et al. Disentangling type 2 diabetes and metformin treatment signatures in the human gut microbiota. Nature 2015, 528, 262-266. [CrossRef]

77. Kim, E.K.; Lee, S.H.; Jhun, J.Y.; Byun, J.K.; Jeong, J.H.; Lee, S.-Y.; Kim, J.K.; Choi, J.Y.; Cho, M.-L. Metformin Prevents Fatty Liver and Improves Balance of White/Brown Adipose in an Obesity Mouse Model by Inducing FGF21. Mediat. Inflamm. 2016, 2016, 1-13. [CrossRef]

78. Karise, I.; Bargut, T.C.; del Sol, M.; Aguila, M.B.; Mandarim-De-Lacerda, C.A. Metformin enhances mitochondrial biogenesis and thermogenesis in brown adipocytes of mice. Biomed. Pharmacother. 2019, 111, 1156-1165. [CrossRef]

79. Lakka, H.-M.; Laaksonen, D.E.; Lakka, T.; Niskanen, L.K.; Kumpusalo, E.; Tuomilehto, J.; Salonen, J.T. The Metabolic Syndrome and Total and Cardiovascular Disease Mortality in Middle-aged Men. JAMA J. Am. Med. Assoc. 2002, 288, 2709-2716. [CrossRef]

80. Thomas, M.; Cooper, M.E.; Zimmet, P. Changing epidemiology of type 2 diabetes mellitus and associated chronic kidney disease. Nat. Rev. Nephrol. 2016, 12, 73-81. [CrossRef]

81. Einarson, T.R.; Acs, A.; Ludwig, C.; Panton, U.H. Prevalence of cardiovascular disease in type 2 diabetes: A systematic literature review of scientific evidence from across the world in 2007-2017. Cardiovasc. Diabetol. 2018, 17, 1-19. [CrossRef] [PubMed]

82. Nichols, G.A.; Gullion, C.M.; Koro, C.E.; Ephross, S.A.; Brown, J.B. The Incidence of Congestive Heart Failure in Type 2 Diabetes. Diabetes Care 2004, 27, 1879-1884. [CrossRef] [PubMed] 
83. Ndumele, C.E.; Matsushita, K.; Lazo, M.; Bello, N.; Blumenthal, R.S.; Gerstenblith, G.; Nambi, V.; Ballantyne, C.M.; Solomon, S.D.; Selvin, E.; et al. Obesity and Subtypes of Incident Cardiovascular Disease. J. Am. Hear. Assoc. 2016, 5, 3921. [CrossRef]

84. Gellert, K.S.; Keil, A.P.; Zeng, D.; Lesko, C.R.; Aubert, R.E.; Avery, C.L.; Lutsey, P.L.; Siega-Riz, A.M.; Windham, B.G.; Heiss, G Reducing the Population Burden of Coronary Heart Disease by Modifying Adiposity: Estimates From the ARIC Study. J. Am. Hear. Assoc. 2020, 9, e012214. [CrossRef] [PubMed]

85. Johansson, I.; Dahlström, U.; Edner, M.; Näsman, P.; Rydén, L.; Norhammar, A. Prognostic Implications of Type 2 Diabetes Mellitus in Ischemic and Nonischemic Heart Failure. J. Am. Coll. Cardiol. 2016, 68, 1404-1416. [CrossRef] [PubMed]

86. Wang, Y.; Negishi, T.; Negishi, K.; Marwick, T.H. Prediction of heart failure in patients with type 2 diabetes mellitus-A systematic review and meta-analysis. Diabetes Res. Clin. Pr. 2015, 108, 55-66. [CrossRef]

87. Levine, B.; Kroemer, G. Biological Functions of Autophagy Genes: A Disease Perspective. Cell 2019, 176, 11-42. [CrossRef]

88. Rangarajan, S.; Bone, N.B.; Zmijewska, A.A.; Jiang, S.; Park, D.W.; Bernard, K.; Locy, M.L.; Ravi, S.; Deshane, J.; Mannon, R.B.; et al. Metformin reverses established lung fibrosis in a bleomycin model. Nat. Med. 2018, 24, 1121-1127. [CrossRef]

89. Fuster, D.G.; Bobulescu, I.A.; Zhang, J.; Wade, J.; Moe, O.W. Characterization of the regulation of renal Na+/H+exchanger NHE3 by insulin. Am. J. Physiol. Physiol. 2007, 292, F577-F585. [CrossRef]

90. Lawrence, S.P.; Holman, G.D.; Koumanov, F. Translocation of the Na+/H+ exchanger 1 (NHE1) in cardiomyocyte responses to insulin and energy-status signalling. Biochem. J. 2010, 432, 515-525. [CrossRef]

91. Gruzdeva, O.V.; Akbasheva, O.E.; Dyleva, Y.A.; Antonova, L.V.; Matveeva, V.G.; Uchasova, E.G.; Fanaskova, E.V.; Karetnikova, V.N.; Иванов, C.; Barbarash, O.L. Adipokine and Cytokine Profiles of Epicardial and Subcutaneous Adipose Tissue in Patients with Coronary Heart Disease. Bull. Exp. Biol. Med. 2017, 163, 608-611. [CrossRef]

92. Venteclef, N.; Guglielmi, V.; Balse, E.; Gaborit, B.; Cotillard, A.; Atassi, F.; Amour, J.; Leprince, P.; Dutour, A.; Clément, K.; et al Human epicardial adipose tissue induces fibrosis of the atrial myocardium through the secretion of adipo-fibrokines. Eur. Hear. J. 2015, 36, 795-805. [CrossRef]

93. Alam, M.S.; Green, R.; De Kemp, R.; Beanlands, R.S.; Chow, B.J.W. Epicardial adipose tissue thickness as a predictor of impaired microvascular function in patients with non-obstructive coronary artery disease. J. Nucl. Cardiol. 2013, 20, 804-812. [CrossRef] [PubMed]

94. Ng, A.C.; Strudwick, M.; van der Geest, R.J.; Ng, A.C.; Gillinder, L.; Goo, S.Y.; Cowin, G.; Delgado, V.; Wang, W.Y.; Bax, J.J. Impact of Epicardial Adipose Tissue, Left Ventricular Myocardial Fat Content, and Interstitial Fibrosis on Myocardial Contractile Function. Circ. Cardiovasc. Imaging 2018, 11, e007372. [CrossRef]

95. Xiao, H.; Ma, X.; Feng, W.; Fu, Y.; Lu, Z.; Xu, M.; Shen, Q.; Zhu, Y.; Zhang, Y. Metformin attenuates cardiac fibrosis by inhibiting the TGF $\beta 1-S m a d 3$ signalling pathway. Cardiovasc. Res. 2010, 87, 504-513. [CrossRef]

96. Yi, H.; Huang, C.; Shi, Y.; Cao, Q.; Zhao, Y.; Zhang, L.; Chen, J.; Pollock, C.A.; Chen, X. Metformin attenuates folic-acid induced renal fibrosis in mice. J. Cell. Physiol. 2018, 233, 7045-7054. [CrossRef]

97. Fan, K.; Wu, K.; Lin, L.; Ge, P.; Dai, J.; He, X.; Hu, K.; Zhang, L. Metformin mitigates carbon tetrachloride-induced TGF- $\beta 1 / S m a d 3$ signaling and liver fibrosis in mice. Biomed. Pharmacother. 2017, 90, 421-426. [CrossRef]

98. Li, L.; Huang, W.; Li, K.; Zhang, K.; Lin, C.; Han, R.; Lu, C.; Wang, Y.; Chen, H.; Sun, F.; et al. Metformin attenuates gefitinibinduced exacerbation of pulmonary fibrosis by inhibition of TGF- $\beta$ signaling pathway. Oncotarget 2015, 6, 43605-43619. [CrossRef]

99. Gamad, N.; Malik, S.; Suchal, K.; Vasisht, S.; Tomar, A.; Arava, S.; Arya, D.S.; Bhatia, J. Metformin alleviates bleomycin-induced pulmonary fibrosis in rats: Pharmacological effects and molecular mechanisms. Biomed. Pharmacother. 2018, 97, 1544-1553. [CrossRef]

100. Malekpour-Dehkordi, Z.; Teimourian, S.; Nourbakhsh, M.; Naghiaee, Y.; Sharifi, R.; Mohiti-Ardakani, J. Metformin reduces fibrosis factors in insulin resistant and hypertrophied adipocyte via integrin/ERK, collagen VI, apoptosis, and necrosis reduction. Life Sci. 2019, 233, 116682. [CrossRef]

101. Liang, D.; Song, Z.; Liang, W.; Li, Y.; Liu, S. Metformin inhibits TGF-beta 1-induced MCP-1 expression through BAMBI-mediated suppression of MEK/ERK1/2 signalling. Nephrology 2018, 24, 481-488. [CrossRef]

102. Al-Damry, N.T.; Attia, H.A.; Al-Rasheed, N.M.; Al-Rasheed, N.M.; Mohamad, R.A.; Al-Amin, M.A.; Dizmiri, N.; Atteya, M. Sitagliptin attenuates myocardial apoptosis via activating LKB-1/AMPK/Akt pathway and suppressing the activity of GSK-3 $\beta$ and $\mathrm{p} 38 \alpha / \mathrm{MAPK}$ in a rat model of diabetic cardiomyopathy. Biomed. Pharmacother. 2018, 107, 347-358. [CrossRef]

103. Shin, H.-S.; Ko, J.; Kim, D.-A.; Ryu, E.-S.; Ryu, H.-M.; Park, S.-H.; Kim, Y.-L.; Oh, E.-S.; Kang, D.-H. Metformin ameliorates the Phenotype Transition of Peritoneal Mesothelial Cells and Peritoneal Fibrosis via a modulation of Oxidative Stress. Sci. Rep. 2017, 7, 5690. [CrossRef]

104. Foretz, M.; Guigas, B.; Viollet, B. Understanding the glucoregulatory mechanisms of metformin in type 2 diabetes mellitus. Nat. Rev. Endocrinol. 2019, 15, 569-589. [CrossRef]

105. Weigert, J.; Neumeier, M.; Wanninger, J.; Bauer, S.; Farkas, S.; Scherer, M.N.; Schnitzbauer, A.; Schäffler, A.; Aslanidis, C.; Schölmerich, J.; et al. Serum Galectin-3 Is Elevated in Obesity and Negatively Correlates with Glycosylated Hemoglobin in Type 2 Diabetes. J. Clin. Endocrinol. Metab. 2010, 95, 1404-1411. [CrossRef]

106. Sharma, U.C.; Pokharel, S.; Van Brakel, T.J.; van Berlo, J.; Cleutjens, J.P.M.; Schroen, B.; André, S.; Crijns, H.J.G.M.; Gabius, H.-J.; Maessen, J.; et al. Galectin-3 Marks Activated Macrophages in Failure-Prone Hypertrophied Hearts and Contributes to Cardiac Dysfunction. Circulation 2004, 110, 3121-3128. [CrossRef] 
107. Asensio-Lopez, M.D.C.; Lax, A.; del Palacio, M.J.F.; Sassi, Y.; Hajjar, R.J.; Figal, D.A.P. Pharmacological inhibition of the mitochondrial NADPH oxidase $4 / \mathrm{PKC} \alpha / \mathrm{Gal}-3$ pathway reduces left ventricular fibrosis following myocardial infarction. Transl. Res. 2018, 199, 4-23. [CrossRef]

108. Zhi, L.; Yuzhang, Z.; Tianliang, H.; Hisatome, I.; Yamamoto, T.; Jidong, C. High Uric Acid Induces Insulin Resistance in Cardiomyocytes In Vitro and In Vivo. PLoS ONE 2016, 11, e0147737. [CrossRef]

109. Su, M.; Sun, L.; Li, W.; Liu, H.; Liu, Y.; Wei, Y.; Yuan, Y.; Zheng, L.; Yin, S.; Dai, C.; et al. Metformin alleviates hyperuricaemiainduced serum FFA elevation and insulin resistance by inhibiting adipocyte hypertrophy and reversing suppressed white adipose tissue beiging. Clin. Sci. 2020, 134, 1537-1553. [CrossRef]

110. Zhu, Y.; Hu, Y.; Huang, T.; Zhang, Y.; Li, Z.; Luo, C.; Luo, Y.; Yuan, H.; Hisatome, I.; Yamamoto, T.; et al. High uric acid directly inhibits insulin signalling and induces insulin resistance. Biochem. Biophys. Res. Commun. 2014, 447, 707-714. [CrossRef]

111. Yuan, H.; Hu, Y.; Zhu, Y.; Zhang, Y.; Luo, C.; Li, Z.; Wen, T.; Zhuang, W.; Zou, J.; Hong, L.; et al. Metformin ameliorates high uric acid-induced insulin resistance in skeletal muscle cells. Mol. Cell. Endocrinol. 2017, 443, 138-145. [CrossRef]

112. Zhang, Y.; Yamamoto, T.; Hisatome, I.; Li, Y.; Cheng, W.; Sun, N.; Cai, B.; Huang, T.; Zhu, Y.; Li, Z.; et al. Uric acid induces oxidative stress and growth inhibition by activating adenosine monophosphate-activated protein kinase and extracellular signal-regulated kinase signal pathways in pancreatic $\beta$ cells. Mol. Cell. Endocrinol. 2013, 375, 89-96. [CrossRef]

113. Soro-Paavonen, A.; Watson, A.M.D.; Li, J.; Paavonen, K.; Koitka, A.; Calkin, A.C.; Barit, D.; Coughlan, M.T.; Drew, B.G.; Lancaster, G.I.; et al. Receptor for Advanced Glycation End Products (RAGE) Deficiency Attenuates the Development of Atherosclerosis in Diabetes. Diabetes 2008, 57, 2461-2469. [CrossRef]

114. La Sala, L.; Prattichizzo, F.; Ceriello, A. The link between diabetes and atherosclerosis. Eur. J. Prev. Cardiol. 2019, 26, 15-24. [CrossRef]

115. Sulistyowati, E.; Permatasari, N.; Widodo, M.A. Combined effects of shear stress and glucose on the morphology, actin filaments, and VE-cadherin of endothelial cells in vitro. IJC Hear. Vasc. 2017, 15, 31-35. [CrossRef]

116. Karnewar, S.; Neeli, P.K.; Panuganti, D.; Kotagiri, S.; Mallappa, S.; Jain, N.; Jerald, M.K.; Kotamraju, S. Metformin regulates mitochondrial biogenesis and senescence through AMPK mediated H3K79 methylation: Relevance in age-associated vascular dysfunction. Biochim. Biophys. Acta (BBA)-Mol. Basis Dis. 2018, 1864, 1115-1128. [CrossRef]

117. de Kreutzenberg, S.V.; Ceolotto, G.; Cattelan, A.; Pagnin, E.; Mazzucato, M.; Garagnani, P.; Borelli, V.; Bacalini, M.G.; Franceschi, C.; Fadini, G.; et al. Metformin improves putative longevity effectors in peripheral mononuclear cells from subjects with prediabetes. A randomized controlled trial. Nutr. Metab. Cardiovasc. Dis. 2015, 25, 686-693. [CrossRef]

118. Saltiel, A.R.; Kahn, C.R. Insulin signalling and the regulation of glucose and lipid metabolism. Nature 2001, 414, 799-806. [CrossRef]

119. Celie, J.W.; Rutjes, N.W.; Keuning, E.D.; Soininen, R.; Heljasvaara, R.; Pihlajaniemi, T.; Dräger, A.M.; Zweegman, S.; Kessler, F.L.; Beelen, R.H.; et al. Subendothelial Heparan Sulfate Proteoglycans Become Major L-Selectin and Monocyte Chemoattractant Protein-1 Ligands upon Renal Ischemia/Reperfusion. Am. J. Pathol. 2007, 170, 1865-1878. [CrossRef]

120. Ceriello, A. Hyperglycaemia and the vessel wall: The pathophysiological aspects on the atherosclerotic burden in patients with diabetes. Eur. J. Cardiovasc. Prev. Rehabil. 2010, 17, s15-s19. [CrossRef]

121. Zhou, Z.; Tang, Y.; Jin, X.; Chen, C.; Lu, Y.; Liu, L.; Shen, C. Metformin Inhibits Advanced Glycation End Products-Induced Inflammatory Response in Murine Macrophages Partly through AMPK Activation and RAGE/NFkB Pathway Suppression. J. Diabetes Res. 2016, 2016, 1-10. [CrossRef]

122. Mazzone, T.; Chait, A.; Plutzky, J. Cardiovascular disease risk in type 2 diabetes mellitus: Insights from mechanistic studies. Lancet 2008, 371, 1800-1809. [CrossRef]

123. Staszel, T.; Zapała, B.; Polus, A.; Sadakierska-Chudy, A.; Kieć-Wilk, B.; Stępień, E.; Wybrańska, I.; Chojnacka, M.; Dembińska-Kieć, A. Role of microRNAs in endothelial cell pathophysiology. Pol. Arch. Intern. Med. 2011, 121, 361-367. [CrossRef]

124. Wang, D.; Deuse, T.; Stubbendorff, M.; Chernogubova, E.; Erben, R.G.; Eken, S.M.; Jin, H.; Li, Y.; Busch, A.; Heeger, C.-H.; et al Local MicroRNA Modulation Using a Novel Anti-miR-21-Eluting Stent Effectively Prevents Experimental In-Stent Restenosis. Arter. Thromb. Vasc. Biol. 2015, 35, 1945-1953. [CrossRef]

125. La Sala, L.; Mrakic-Sposta, S.; Micheloni, S.; Prattichizzo, F.; Ceriello, A. Glucose-sensing microRNA-21 disrupts ROS homeostasis and impairs antioxidant responses in cellular glucose variability. Cardiovasc. Diabetol. 2018, 17, 1-14. [CrossRef]

126. Zhou, J.; Wang, K.C.; Wu, W.; Subramaniam, S.; Shyy, J.Y.; Chiu, J.J.; Li, J.Y.; Chien, S. MicroRNA-21 targets peroxisome proliferators-activated receptor- $\alpha$ in an autoregulatory loop to modulate flow-induced endothelial inflammation. Proc. Natl. Acad. Sci. USA 2011, 108, 10355-10360. [CrossRef]

127. Kumarswamy, R.; Volkmann, I.; Thum, T. Regulation and function of miRNA-21 in health and disease. RNA Biol. $2011,8,706-713$. [CrossRef]

128. Schram, M.; Chaturvedi, N.; Schalkwijk, C.G.; Fuller, J.H.; Stehouwer, C.D. EURODIAB prospective complications study groupmarkers of inflammation are cross-sectionally associated with microvascular complications and cardiovascular disease in type 1 diabetes-the EURODIAB prospective complications study. Diabetologia 2005, 48, 370-378. [CrossRef]

129. Demirsoy, İ.H.; Ertural, D.Y.; Balci, Ş.; Çinkir, Ü.; Sezer, K.; Tamer, L.; Aras, N. Profiles of Circulating miRNAs Following Metformin Treatment in Patients with Type 2 Diabetes. J. Med. Biochem. 2018, 4, 499. [CrossRef]

130. Alimoradi, N.; Firouzabadi, N.; Fatehi, R. Metformin and insulin-resistant related diseases: Emphasis on the role of microRNAs. Biomed. Pharmacother. 2021, 139, 111662. [CrossRef] 
131. Ahmed, F.W.; Bakhashab, S.; Bastaman, I.T.; Crossland, R.E.; Glanville, M.; Weaver, J.U. Anti-Angiogenic miR-222, miR-195, and miR-21a Plasma Levels in T1DM Are Improved by Metformin Therapy, Thus Elucidating Its Cardioprotective Effect: The MERIT Study. Int. J. Mol. Sci. 2018, 19, 3242. [CrossRef]

132. Deng, N.; Guo, R.; Zheng, B.; Li, T.; Liu, R.H. IRS-1/PI3K/Akt pathway and miRNAs are involved in whole grain highland barley (Hordeum vulgareL.) ameliorating hyperglycemia of db/db mice. Food Funct. 2020, 11, 9535-9546. [CrossRef]

133. Mensà, E.; Giuliani, A.; Matacchione, G.; Gurău, F.; Bonfigli, A.R.; Romagnoli, F.; De Luca, M.; Sabbatinelli, J.; Olivieri, F. Circulating miR-146a in healthy aging and type 2 diabetes: Age- and gender-specific trajectories. Mech. Ageing Dev. 2019, 180, 1-10. [CrossRef]

134. Gou, C.; Ji, Q. Coupled cascade regression from real and synthesized faces for simultaneous landmark detection and head pose estimation. J. Electron. Imaging 2020, 29, 023028. [CrossRef]

135. Federici, M.; Menghini, R.; Mauriello, A.; Hribal, M.L.; Ferrelli, F.; Lauro, D.; Sbraccia, P.; Spagnoli, L.G.; Sesti, G.; Lauro, R Insulin-Dependent Activation of Endothelial Nitric Oxide Synthase Is Impaired by O-Linked Glycosylation Modification of Signaling Proteins in Human Coronary Endothelial Cells. Circulation 2002, 106, 466-472. [CrossRef]

136. Deng, M.; Su, D.; Xu, S.; Little, P.J.; Feng, X.; Tang, L.; Shen, A. Metformin and Vascular Diseases: A Focused Review on Smooth Muscle Cell Function. Front. Pharmacol. 2020, 11, 635. [CrossRef]

137. Cai, Z.; Ding, Y.; Zhang, M.; Lu, Q.; Wu, S.; Zhu, H.; Song, P.; Zou, M.-H. Ablation of Adenosine Monophosphate-Activated Protein Kinase $\alpha 1$ in Vascular Smooth Muscle Cells Promotes Diet-Induced Atherosclerotic Calcification In Vivo. Circ. Res. 2016, 119, 422-433. [CrossRef]

138. Cao, X.; Li, H.; Tao, H.; Wu, N.; Yu, L.; Zhang, D.; Lu, X.; Zhu, J.; Lu, Z.; Zhu, Q. Metformin Inhibits Vascular Calcification in Female Rat Aortic Smooth Muscle Cells via the AMPK-eNOS-NO Pathway. Endocrinology 2013, 154, 3680-3689. [CrossRef]

139. Ma, W.-Q.; Sun, X.-J.; Wang, Y.; Zhu, Y.; Han, X.-Q.; Liu, N.-F. Restoring mitochondrial biogenesis with metformin attenuates $\beta$ GP-induced phenotypic transformation of VSMCs into an osteogenic phenotype via inhibition of PDK4/oxidative stress-mediated apoptosis. Mol. Cell. Endocrinol. 2019, 479, 39-53. [CrossRef]

140. Durham, A.L.; Speer, M.Y.; Scatena, M.; Giachelli, C.M.; Shanahan, C.M. Role of smooth muscle cells in vascular calcification: Implications in atherosclerosis and arterial stiffness. Cardiovasc. Res. 2018, 114, 590-600. [CrossRef]

141. Evdokimenko, A.N.; Anufriev, P.L.; Kulichenkova, K.N.; Gulevskaya, T.S.; Tanashyan, M. Morphometric characteristics of neovascularization of carotid atherosclerotic plaques. Arkhiv Patol. 2018, 80, 24-29. [CrossRef]

142. Seneviratne, A.; Cave, L.; Hyde, G.; Moestrup, S.K.; Carling, D.; Mason, J.; Haskard, D.O.; Boyle, J.J. Metformin directly suppresses atherosclerosis in normoglycaemic mice via haematopoietic adenosine monophosphate-activated protein kinase. Cardiovasc. Res. 2021, 117, 1295-1308. [CrossRef]

143. Dewanjee, S.; Vallamkondu, J.; Kalra, R.S.; John, A.; Reddy, P.H.; Kandimalla, R. Autophagy in the diabetic heart: A potential pharmacotherapeutic target in diabetic cardiomyopathy. Ageing Res. Rev. 2021, 68, 101338. [CrossRef]

144. Packer, M. Differential Pathophysiological Mechanisms in Heart Failure With a Reduced or Preserved Ejection Fraction in Diabetes. JACC Hear. Fail. 2021, 9, 535-549. [CrossRef]

145. Rabkin, S.W. The Relationship Between Epicardial Fat and Indices of Obesity and the Metabolic Syndrome: A Systematic Review and Meta-Analysis. Metab. Syndr. Relat. Disord. 2014, 12, 31-42. [CrossRef]

146. Greulich, S.; Maxhera, B.; Vandenplas, G.; de Wiza, D.H.; Smiris, K.; Mueller, H.; Heinrichs, J.; Blumensatt, M.; Cuvelier C.; Akhyari, P.; et al. Secretory Products From Epicardial Adipose Tissue of Patients With Type 2 Diabetes Mellitus Induce Cardiomyocyte Dysfunction. Circulation 2012, 126, 2324-2334. [CrossRef]

147. Packer, M. Epicardial Adipose Tissue May Mediate Deleterious Effects of Obesity and Inflammation on the Myocardium. J. Am. Coll. Cardiol. 2018, 71, 2360-2372. [CrossRef]

148. Bos, M.J.; Koudstaal, P.J.; Hofman, A.; Witteman, J.C.; Breteler, M.M. Uric Acid Is a Risk Factor for Myocardial Infarction and Stroke. Stroke 2006, 37, 1503-1507. [CrossRef]

149. Huang, H.; Huang, B.; Li, Y.; Huang, Y.; Li, J.; Yao, H.; Jing, X.; Chen, J.; Wang, J. Uric acid and risk of heart failure: A systematic review and meta-analysis. Eur. J. Hear. Fail. 2013, 16, 15-24. [CrossRef]

150. Li, Z.; Shen, Y.; Chen, Y.; Zhang, G.; Cheng, J.; Wang, W. High Uric Acid Inhibits Cardiomyocyte Viability Through the ERK/P38 Pathway via Oxidative Stress. Cell. Physiol. Biochem. 2018, 45, 1156-1164. [CrossRef]

151. Kang, D.-H.; Nakagawa, T.; Feng, L.; Watanabe, S.; Han, L.; Mazzali, M.; Truong, L.; Harris, R.; Johnson, R. A Role for Uric Acid in the Progression of Renal Disease. J. Am. Soc. Nephrol. 2002, 13, 2888-2897. [CrossRef]

152. Bugger, H.; Abel, E.D. Molecular mechanisms of diabetic cardiomyopathy. Diabetologia 2014, 57, 660-671. [CrossRef]

153. Cai, X.; Liu, X.; Sun, L.; He, Y.; Zheng, S.; Zhang, Y.; Huang, Y. Prediabetes and the risk of heart failure: A meta-analysis. Diabetes, Obes. Metab. 2021, 23, 1746-1753. [CrossRef]

154. Yang, C.D.; Shen, Y.; Lu, L.; Ding, F.H.; Yang, Z.K.; Zhang, R.Y.; Shen, W.F.; Jin, W.; Wang, X.Q. Insulin resistance and dysglycemia are associated with left ventricular remodeling after myocardial infarction in non-diabetic patients. Cardiovasc. Diabetol. 2019, 18, 1-11. [CrossRef]

155. Wagner, R.; Heni, M.; Tabák, A.G.; Machann, J.; Schick, F.; Randrianarisoa, E.; de Angelis, M.H.; Birkenfeld, A.L.; Stefan, N.; Peter, A.; et al. Pathophysiology-based subphenotyping of individuals at elevated risk for type 2 diabetes. Nat. Med. 2021, 27, 49-57. [CrossRef] 
156. Meijles, D.N.; Zoumpoulidou, G.; Markou, T.; Rostron, K.A.; Patel, R.; Lay, K.; Handa, B.S.; Wong, B.; Sugden, P.H.; Clerk, A. The cardiomyocyte "redox rheostat": Redox signalling via the AMPK-mTOR axis and regulation of gene and protein expression balancing survival and death. J. Mol. Cell. Cardiol. 2019, 129, 118-129. [CrossRef]

157. Krzysiak, T.C.; Thomas, L.; Choi, Y.-J.; Auclair, S.; Qian, Y.; Luan, S.; Krasnow, S.M.; Thomas, L.L.; Koharudin, L.M.; Benos, P.V.; et al. An Insulin-Responsive Sensor in the SIRT1 Disordered Region Binds DBC1 and PACS-2 to Control Enzyme Activity. Mol. Cell 2018, 72, 985-998.e7. [CrossRef]

158. Paula-Gomes, S.; Gonçalves, D.A.P.; Baviera, A.M.; Zanon, N.M.; Navegantes, L.C.C.; Kettelhut, I.C. Insulin Suppresses Atrophyand Autophagy-related Genes in Heart Tissue and Cardiomyocytes Through AKT/FOXO Signaling. Horm. Metab. Res. 2013, 45, 849-855. [CrossRef]

159. Baek, J.H.; Jin, S.-M.; Bae, J.C.; Jee, J.H.; Yu, T.Y.; Kim, S.K.; Hur, K.Y.; Lee, M.-K.; Kim, J.H. Serum Calcium and the Risk of Incident Metabolic Syndrome: A 4.3-Year Retrospective Longitudinal Study. Diabetes Metab. J. 2017, 41, 60-68. [CrossRef]

160. Taganov, K.D.; Boldin, M.; Chang, K.-J.; Baltimore, D. NF- B-dependent induction of microRNA miR-146, an inhibitor targeted to signaling proteins of innate immune responses. Proc. Natl. Acad. Sci. USA 2006, 103, 12481-12486. [CrossRef]

161. Salvatore, T.; Galiero, R.; Caturano, A.; Vetrano, E.; Rinaldi, L.; Coviello, F.; Di Martino, A.; Albanese, G.; Marfella, R.; Sardu, C.; et al. Effects of Metformin in Heart Failure: From Pathophysiological Rationale to Clinical Evidence. Biomolecules 2021, 11, 1834. [CrossRef]

162. Jiao, Z.; Chen, Y.; Xie, Y.; Li, Y.; Li, Z. Metformin protects against insulin resistance induced by high uric acid in cardiomyocytes via AMPK signalling pathways in vitro and in vivo. J. Cell. Mol. Med. 2021, 25, 6733-6745. [CrossRef]

163. Ohkura, T.; Fujioka, Y.; Nakanishi, R.; Shiochi, H.; Sumi, K.; Yamamoto, N.; Matsuzawa, K.; Izawa, S.; Ohkura, H.; Ueta, E.; et al Low serum galectin-3 concentrations are associated with insulin resistance in patients with type 2 diabetes mellitus. Diabetol. Metab. Syndr. 2014, 6, 106. [CrossRef]

164. Dong, R.; Zhang, M.; Hu, Q.; Zheng, S.; Soh, A.; Zheng, Y.; Yuan, H. Galectin-3 as a novel biomarker for disease diagnosis and a target for therapy (Review). Int. J. Mol. Med. 2018, 41, 599-614. [CrossRef]

165. Bai, J.; Zhang, N.; Hua, Y.; Wang, B.; Ling, L.; Ferro, A.; Xu, B. Metformin Inhibits Angiotensin II-Induced Differentiation of Cardiac Fibroblasts into Myofibroblasts. PLoS ONE 2013, 8, e72120. [CrossRef]

166. Mummidi, S.; Das, N.A.; Carpenter, A.J.; Kandikattu, H.; Krenz, M.; Siebenlist, U.; Valente, A.J.; Chandrasekar, B. Metformin inhibits aldosterone-induced cardiac fibroblast activation, migration and proliferation in vitro, and reverses aldosterone+saltinduced cardiac fibrosis in vivo. J. Mol. Cell. Cardiol. 2016, 98, 95-102. [CrossRef]

167. Lee, J.H.; Kim, J.H.; Kim, J.S.; Chang, J.W.; Kim, S.B.; Park, J.S.; Lee, S.K. AMP-activated protein kinase inhibits TGF- $\beta$-, angiotensin II-, aldosterone-, high glucose-, and albumin-induced epithelial-mesenchymal transition. Am. J. Physiol. Physiol. 2013, 304, F686-F697. [CrossRef]

168. Chen, R.; Feng, Y.; Wu, J.; Song, Y.; Li, H.; Shen, Q.; Li, D.; Zhang, J.; Lu, Z.; Xiao, H.; et al. Metformin attenuates angiotensin II-induced TGF $\beta 1$ expression by targeting hepatocyte nuclear factor-4- $\alpha$. J. Cereb. Blood Flow Metab. 2017, 175, 1217-1229. [CrossRef]

169. Kanamori, H.; Naruse, G.; Yoshida, A.; Minatoguchi, S.; Watanabe, T.; Kawaguchi, T.; Yamada, Y.; Mikami, A.; Kawasaki, M.; Takemura, G.; et al. Metformin Enhances Autophagy and Provides Cardioprotection in $\delta$-Sarcoglycan Deficiency-Induced Dilated Cardiomyopathy. Circ. Hear. Fail. 2019, 12, e005418. [CrossRef]

170. Gao, J.; Yuan, J.; Wang, Q.; Lei, T.; Shen, X.; Cui, B.; Zhang, F.; Ding, W.; Lu, Z. Metformin protects against PM2.5-induced lung injury and cardiac dysfunction independent of AMP-activated protein kinase $\alpha 2$. Redox Biol. 2020, 28, 101345. [CrossRef]

171. Tikoo, K.; Sharma, E.; Amara, V.R.; Pamulapati, H.; Dhawale, V.S. Metformin Improves Metabolic Memory in High Fat Diet (HFD)-induced Renal Dysfunction. J. Biol. Chem. 2016, 291, 21848-21856. [CrossRef]

172. Shen, Y.; Miao, N.; Xu, J.; Gan, X.; Xu, D.; Zhou, L.; Xue, H.; Zhang, W.; Lu, L. Metformin Prevents Renal Fibrosis in Mice with Unilateral Ureteral Obstruction and Inhibits Ang II-Induced ECM Production in Renal Fibroblasts. Int. J. Mol. Sci. 2016, 17, 146. [CrossRef]

173. Neven, E.; Vervaet, B.; Brand, K.; Gottwald-Hostalek, U.; Opdebeeck, B.; De Maré, A.; Verhulst, A.; Lalau, J.-D.; Kamel, S.; De Broe, M.E.; et al. Metformin prevents the development of severe chronic kidney disease and its associated mineral and bone disorder. Kidney Int. 2018, 94, 102-113. [CrossRef]

174. Lin, C.-X.; Li, Y.; Liang, S.; Tao, J.; Zhang, L.-S.; Su, Y.-F.; Huang, Y.-X.; Zhao, Z.-K.; Liu, S.-Y.; Zheng, J.-M. Metformin Attenuates Cyclosporine A-induced Renal Fibrosis in Rats. Transplantation 2019, 103, e285-e296. [CrossRef]

175. Luo, T.; Nocon, A.; Fry, J.; Sherban, A.; Rui, X.; Jiang, B.; Xu, X.J.; Han, J.; Yan, Y.; Yang, Q.; et al. AMPK Activation by Metformin Suppresses Abnormal Extracellular Matrix Remodeling in Adipose Tissue and Ameliorates Insulin Resistance in Obesity. Diabetes 2016, 65, 2295-2310. [CrossRef]

176. Biondo, L.A.; Batatinha, H.A.; Souza, C.O.; Teixeira, A.A.S.; Silveira, L.; Alonso-Vale, M.I.; Oyama, L.M.; Alves, M.J.; Seelaender, M.; Neto, J.R. Metformin Mitigates Fibrosis and Glucose Intolerance Induced by Doxorubicin in Subcutaneous Adipose Tissue. Front. Pharmacol. 2018, 9, 452. [CrossRef]

177. McCloskey, C.W.; Cook, D.P.; Kelly, B.S.; Azzi, F.; Allen, C.H.; Forsyth-Greig, A.; Upham, J.; Rayner, K.J.; Gray, D.A.; Boyd, R.W.; et al. Metformin Abrogates Age-Associated Ovarian Fibrosis. Clin. Cancer Res. 2019, 26, 632-642. [CrossRef] 
178. Bugianesi, E.; Gentilcore, E.; Manini, R.; Natale, S.; Vanni, E.; Villanova, N.; David, E.; Rizzetto, M.; Marchesini, G. A Randomized Controlled Trial of Metformin versus Vitamin E or Prescriptive Diet in Nonalcoholic Fatty Liver Disease. Am. J. Gastroenterol. 2005, 100, 1082-1090. [CrossRef]

179. Guo, S.; Meng, X.-W.; Yang, X.-S.; Liu, X.-F.; Ou-Yang, C.-H.; Liu, C. Curcumin administration suppresses collagen synthesis in the hearts of rats with experimental diabetes. Acta Pharmacol. Sin. 2018, 39, 195-204. [CrossRef]

180. Shin, J.; Toyoda, S.; Nishitani, S.; Fukuhara, A.; Kita, S.; Otsuki, M.; Shimomura, I. Possible Involvement of Adipose Tissue in Patients With Older Age, Obesity, and Diabetes With SARS-CoV-2 Infection (COVID-19) via GRP78 (BIP/HSPA5): Significance of Hyperinsulinemia Management in COVID-19. Diabetes 2021, 70, 2745-2755. [CrossRef]

181. Ibrahim, I.M.; Abdelmalek, D.H.; Elfiky, A.A. GRP78: A cell's response to stress. Life Sci. 2019, 226, 156-163. [CrossRef]

182. Ravindran, S.; Kuruvilla, V.; Wilbur, K.; Munusamy, S. Nephroprotective Effects of Metformin in Diabetic Nephropathy. J. Cell. Physiol. 2017, 232, 731-742. [CrossRef]

183. Cas, A.D.; Khan, S.; Butler, J.; Mentz, R.J.; Bonow, R.O.; Avogaro, A.; Tschoepe, D.; Doehner, W.; Greene, S.J.; Senni, M.; et al. Impact of Diabetes on Epidemiology, Treatment, and Outcomes of Patients With Heart Failure. JACC Hear. Fail. 2015, 3, 136-145. [CrossRef]

184. Fácila, L.; Fabregat-Andrés, Ó.; Bertomeu, V.; Navarro, J.P.; Miñana, G.; García-Blas, S.; Valero, E.; Morell, S.; Sanchis, J.; Núñez, J. Metformin and risk of long-term mortality following an admission for acute heart failure. J. Cardiovasc. Med. 2017, 18, 69-73. [CrossRef]

185. Dunlay, S.M.; Givertz, M.M.; Aguilar, D.; Allen, L.A.; Chan, M.; Desai, A.S.; Deswal, A.; Dickson, V.V.; Kosiborod, M.N.; Lekavich, C.L.; et al. Type 2 Diabetes Mellitus and Heart Failure: A Scientific Statement From the American Heart Association and the Heart Failure Society of America: This statement does not represent an update of the 2017 ACC/AHA/HFSA heart failure guideline update. Circulation 2019, 140, e294-e324. [CrossRef]

186. Salvatore, T.; Pafundi, P.C.; Morgillo, F.; Di Liello, R.; Galiero, R.; Nevola, R.; Marfella, R.; Monaco, L.; Rinaldi, L.; Adinolfi, L.E.; et al. Metformin: An old drug against old age and associated morbidities. Diabetes Res. Clin. Pr. 2020, 160, 108025. [CrossRef]

187. Salvatore, T.; Pafundi, P.C.; Galiero, R.; Rinaldi, L.; Caturano, A.; Vetrano, E.; Aprea, C.; Albanese, G.; Di Martino, A.; Ricozzi, C.; et al. Can Metformin Exert as an Active Drug on Endothelial Dysfunction in Diabetic Subjects? Biomedicines 2020, 9, 3. [CrossRef]

188. Kravchuk, E.; Grineva, E.; Bairamov, A.; Galagudza, M.; Vlasov, T. The Effect of Metformin on the Myocardial Tolerance to Ischemia-Reperfusion Injury in the Rat Model of Diabetes Mellitus Type II. Exp. Diabetes Res. 2011, 2011, 1-5. [CrossRef]

189. Dziubak, A.; Wójcicka, G.; Wojtak, A.; Bełtowski, J. Metabolic Effects of Metformin in the Failing Heart. Int. J. Mol. Sci. 2018, 19, 2869. [CrossRef]

190. Fung, C.S.C.; Wan, E.Y.F.; Wong, C.K.H.; Jiao, F.; Chan, A.K.C. Effect of metformin monotherapy on cardiovascular diseases and mortality: A retrospective cohort study on Chinese type 2 diabetes mellitus patients. Cardiovasc. Diabetol. 2015, 14, 1-14. [CrossRef]

191. Roussel, R.; Travert, F.; Pasquet, B.; Wilson, P.W.F.; Smith, S.C.; Goto, S.; Ravaud, P.; Marre, M.; Porath, A.; Bhatt, D.L.; et al. Metformin Use and Mortality Among Patients With Diabetes and AtherothrombosisMetformin Use With Diabetes and Atherothrombosis. Arch. Intern. Med. 2010, 170, 1892-1899. [CrossRef]

192. Ohman, E.M.; Bhatt, D.L.; Steg, P.G.; Goto, S.; Hirsch, A.T.; Liau, C.-S.; Mas, J.-L.; Richard, A.-J.; Röther, J.; Wilson, P.W. The REduction of Atherothrombosis for Continued Health (REACH) Registry: An international, prospective, observational investigation in subjects at risk for atherothrombotic events-study design. Am. Hear. J. 2006, 151, 786.e1-786.e10. [CrossRef]

193. Ibanez, B.; James, S.; Agewall, S.; Antunes, M.J.; Bucciarelli-Ducci, C.; Bueno, H.; Caforio, A.L.P.; Crea, F.; Goudevenos, J.A.; Halvorsen, S.; et al. 2017 ESC Guidelines for the management of acute myocardial infarction in patients presenting with STsegment elevation: The Task Force for the management of acute myocardial infarction in patients presenting with ST-segment elevation of the European Society of Cardiology (ESC). Eur. Heart J. 2018, 39, 119-177. [CrossRef]

194. Nunes, J.P.L.; Melão, F.; Godinho, A.R.; Rodrigues, J.D.; Maciel, M.J. Antidiabetic therapy at admission and survival in diabetic patients with acute myocardial infarction. Porto Biomed. J. 2017, 2, 111-114. [CrossRef]

195. Komaru, Y.; Takeuchi, T.; Suzuki, L.; Asano, T.; Urayama, K.Y. Recurrent cardiovascular events in patients with newly diagnosed acute coronary syndrome: Influence of diabetes and its management with medication. J. Diabetes Its Complicat. $2019,34,107511$. [CrossRef]

196. Eurich, D.T.; Weir, D.L.; Majumdar, S.R.; Tsuyuki, R.T.; Johnson, J.; Tjosvold, L.; Vanderloo, S.E.; McAlister, F. Comparative Safety and Effectiveness of Metformin in Patients With Diabetes Mellitus and Heart Failure. Circ. Hear. Fail. 2013, 6, 395-402. [CrossRef]

197. Halabi, A.; Sen, J.; Huynh, Q.; Marwick, T.H. Metformin treatment in heart failure with preserved ejection fraction: A systematic review and meta-regression analysis. Cardiovasc. Diabetol. 2020, 19, 1-10. [CrossRef]

198. Broskey, N.T.; Zou, K.; Dohm, G.L.; Houmard, J.A. Plasma Lactate as a Marker for Metabolic Health. Exerc. Sport Sci. Rev. 2020, 48, 119-124. [CrossRef]

199. Ferguson, B.S.; Rogatzki, M.J.; Goodwin, M.L.; Kane, D.A.; Rightmire, Z.; Gladden, L.B. Lactate metabolism: Historical context, prior misinterpretations, and current understanding. Eur. J. Appl. Physiol. 2018, 118, 691-728. [CrossRef]

200. Goodwin, M.L.; Gladden, L.B.; Nijsten, M.W.N. Lactate-Protected Hypoglycemia (LPH). Front. Neurosci. 2020, 14, 920. [CrossRef]

201. Brooks, G.A. Lactate as a fulcrum of metabolism. Redox Biol. 2020, 35, 101454. [CrossRef]

202. Kajbaf, F.; Lalau, J.-D. The criteria for metformin-associated lactic acidosis: The quality of reporting in a large pharmacovigilance database. Diabet. Med. 2013, 30, 345-348. [CrossRef] 
203. Salvatore, T.; Pafundi, P.C.; Marfella, R.; Sardu, C.; Rinaldi, L.; Monaco, L.; Ricozzi, C.; Imbriani, S.; Nevola, R.; Adinolfi, L.E.; et al. Metformin lactic acidosis: Should we still be afraid? Diabetes Res. Clin. Pr. 2019, 157, 107879. [CrossRef]

204. Tomita, I.; Kume, S.; Sugahara, S.; Osawa, N.; Yamahara, K.; Yasuda-Yamahara, M.; Takeda, N.; Chin-Kanasaki, M.; Kaneko, T.; Mayoux, E.; et al. SGLT2 Inhibition Mediates Protection from Diabetic Kidney Disease by Promoting Ketone Body-Induced mTORC1 Inhibition. Cell Metab. 2020, 32, 404-419.e6. [CrossRef]

205. Verma, S. Potential Mechanisms of Sodium-Glucose Co-Transporter 2 Inhibitor-Related Cardiovascular Benefits. Am. J. Cardiol. 2019, 124, S36-S44. [CrossRef] 